\title{
5 Cervantes, Entremés del Retablo de las maravillas
}

In Madrid in 1615 (the same year in which the second part of the Quijote appeared), two years after the publication of his Novelas ejemplares and one year after the publication of the satirical epic poem Viaje al Parnaso) Cervantes published a collection of dramatic works entitled Ocho comedias y ocho entremeses nuevos, nunca representados [Eight Plays and Eight New Interludes, Never Performed]. The reason for the addition of 'never performed,' is elucidated in the 'Prologue to the Reader,' where Cervantes differentiates between the current plays and some twenty to thirty earlier comedias, all of which, he claims, had been performed on stage. Regarding the earlier plays he further remarks that he had reduced the number of their acts from the usual five to three and that, to general and pleasurable applause from the audience, he had brought the imaginings and secret thoughts of the soul to the stage by making 'moral characters' appear. ${ }^{774}$ (Cervantes is referring here to his first period of dramatic creation in the 1580s, from which only the plays El cerco de Numancia, Los tratos de Argel, and La conquista de Jerusalén have survived.) Cervantes then goes on to say that he, having other things to do that occupied him, abandoned the writing of plays, ${ }^{775}$ noting that Spanish theater went on to be completely dominated by the comedia nueva of Lope de Vega, whom he calls the 'great Lope,' and the 'monster of nature' ('a tremendous natural talent'), and his fellow playwrights:

[...] entró luego el monstruo de naturaleza, el gran Lope de Vega, y alzóse con la monarquía cómica; avasalló y puso debajo de su juridición a todos los farsantes; llenó el mundo de comedias proprias, felices y bien razonadas, y tantas, que pasan de diez mil pliegos los que tiene escritos [...]. [...] todos éstos [Mira de Amescua, Guillén de Castro, Luis Vélez de Guevara etc.] y otros algunos han ayudado a llevar esta gran máquina al gran Lope. ${ }^{776}$

774 “[...] me atreví a reducir las comedias a tres jornadas, de cinco que tenían; mostré, o, por mejor decir, fui el primero que representase las imaginaciones y los pensamientos escondidos del alma, sacando figuras morales al teatro, con general y gustoso aplauso de los oyentes; compuse en este tiempo hasta veinte comedias o treinta, que todas ellas se recitaron sin que se les ofreciese ofrenda de pepinos ni de otra cosa arrojadiza; corrieron su carrera sin silbos, gritas ni barahúndas" (Miguel de Cervantes Saavedra, "Prólogo al lector," in: Miguel de Cervantes, Entremeses, ed. Nicholas Spadaccini, 19th ed., Madrid 2009, pp. 91-94, here pp. 92 f.).

775 "Tuve otras cosas en que ocuparme; dejé la pluma y las comedias [...]” (p. 93).

776 Ibid.

Ә Open Access. (C) 2019 Leonie Pawlita, published by De Gruyter. (cc) BY-NC-ND This work is licensed under a Creative Commons Attribution-NonCommercial-NoDerivatives 4.0 International License.

https://doi.org/10.1515/9783110660586-006 
After once again taken up the writing of plays, after a break of many years, he (Cervantes) could not find a single autor willing to produce them. ${ }^{777}$ Not disposed to condemn his comedias and entremeses to 'eternal silence,' which was clearly the intention of the theater directors, who, in their focus on Lope de Vega's comedia, had rejected his plays, Cervantes decided to have them printed, because:

Querría que fuesen las mejores del mundo, o a lo menos razonables; tú lo verás lector, y si hallares que tienen alguna cosa buena, topando a aquel mi maldiciente autor, dile [...] que advierta que no tienen necedades patentes y descubiertas, y que el verso es el mismo que piden las comedias, que ha de ser, de los tres estilos, el ínfimo, y que el lenguaje de los entremeses es proprio de las figuras que en ellos se introducen; y que, para enmienda de todo esto, le ofrezco una comedia que estoy componiendo, y la intitulo $\mathrm{El}$ engaño a los ojos, que, si no me engaño, le ha de dar contento. ${ }^{778}$

The title of the new play he mentions, El engaño a los ojos [The Deception of the Eyes], is a reference to skepticism, particularly to its main argument regarding the unreliability of sensory perception. This refers to a topic that Cervantes returns to repeatedly throughout his works, namely, the playing with and problematization of the complex relationship between issues such as 'deception and truth,' 'fiction and reality,' and 'illusion and reality.' One of the most wellknown examples is of course the Quijote. Another fascinating example of Cervantes' masterly multi-layered approach to this theme is the Entremés del Retablo de las maravillas [Interlude of The Retable of Marvels or The (Puppet) Show of Wonders], the sixth of the eight interludes, written in prose and containing a 'play within a play.'

Unlike the other plays reviewed in this study, the play written by Cervantes that will be discussed here, although accessible to the reading public from 1615 on, was never performed onstage, at least not during his lifetime. Another differentiating factor concerns the genre. It is brief dramatic form, the main genre of the teatro menor, and, furthermore, a genuinely comic genre. Entremeses (interludes) are farcical, burlesque, and satirical one act plays, often including dance and music, performed between the first and second acts of a comedia, isolated in content from the main plot. They also served as entertaining intermissions during

\footnotetext{
777 “Algunos años ha que volví yo a mi antigua ociosidad, y, pensando que aún duraban los siglos donde corrían mis alabanzas, volví a componer algunas comedias, pero no hallé pájaros en los nidos de antaño; quiero decir que no hallé autor que me las pidiese, puesto que sabían que las tenía; [...] me dijo un librero que él me las comprara si un autor de título no le hubiera dicho que de mi prosa se podía esperar mucho, pero que del verso, nada” (pp. 93 f.).
}

778 P. 94. 
the performance of the autos sacramentales. ${ }^{779}$ Cervantes, however, conceived and used this generic mode in particular ways, creating short theater pieces that are hybrid in nature and complex in both form and content. ${ }^{780}$ While it might be seen as problematic to include a 'comedy' in this current study of skepticism in drama (by 'comedy' I mean a play with a purely comic and light-hearted content, in line with the traditions of the 'comical genre'), ${ }^{781}$ it is exactly this combination of the comic (as appropriate for an entremés) with a dimension of seriousness that was one of the hallmarks of Cervantes' approach to the genre, especially evident in El retablo de las maravillas, which warrants its inclusion.

Cervantes' source for El retablo de las maravillas is believed to be Juan Manuel's (1282-1348) Conde Lucanor ("Exemplo XXXII. De lo que contesçió a un rey con unos burladores que fizieron el paño"), the popular collection of

779 To illustrate, see Tesoro of Covarrubias, the first Spanish dictionary, which defines entremés as theatrical works of brevity, and of a subordinate status to the comedia, intended to be essentially funny, with the sole purpose of pure, amusing entertainment: "ENTREMES, està corrompido del Italiano, intremeso, q[ue] vale tanto como entremetido, o enxerido, y es propiame[n]te vna representacio[n] de risa y graciosa, que se entremete entre vn acto y otro de la comedia, para alegrar, y espaciar el auditorio" (Sebastián de Covarrubias y Orozco, Tesoro de la lengua castellana o española, Madrid 1611, Primera Parte, fol. 356v; my italics). On the genesis of the genre in Spain, cf. Eugenio Asensio, Itinerario del entremés: Desde Lope de Rueda a Quiñones de Benavente, con cinco entremeses de D. Francisco de Quevedo, 2nd ed., Madrid 1971 (1st ed. 1965); cf., furthermore, the concise and enlightening presentation in one of the fundamental recent comprehensive studies of Cervantes' theatrical texts: Jesús G. Maestro, La escena imaginaria: Poética del teatro de Miguel de Cervantes, Madrid/Frankfurt am Main 2000, pp. 201-212 (“De la commedia dell'arte al entremés” [pp. 201-204]; “El entremés como género literario y como forma de espectáculo” [pp. 205-212]) (after Jean Canavaggio, Cervantès dramaturge: Un théâtre à naître, Paris 1977 and later Stanislav Zimic, El teatro de Cervantes, Madrid 1992). Regarding global studies on Cervantes' Entremeses may be mentioned: Patricia Ann Kenworthy, The Entremeses of Cervantes: The Dramaturgy of Illusion, Diss. Tucson, AZ 1976; Cory A. Reed, The Novelist as Playwright: Cervantes and the 'Entremés nuevo', New York/Berlin/Frankfurt am Main 1993; Vicente Pérez de León, Tablas destempladas: Los entremeses de Cervantes a examen, Alcalá de Henares 2005.

780 Cf., e.g., Reed (The Novelist As Playwright [cf. note 779]), who interprets the Cervantine entremés - based on Bakhtin's study of the novel - as a 'novelized drama' (on Retablo de las maravillas, cf. pp. 150-172).

781 Not 'comedy' in the sense of the medieval Christian connotation of the term comoedia respectively commedia as 'poem-' (evident in Dante's Divina Commedia [1307]) or 'play with happy outcome' (as opposed to the bloody ending and tragic outcome of the 'tragedy'). The 'good ending' (restoration of order) to the exploration of more serious themes in Early Modern Spanish drama, the 'comedia nueva,' may refer to this context (and thus also to its function within the ideology of the Counter-Reformation). 
brief Spanish narratives printed in Seville in $1575 .^{782}$ It is more prominently known as the source for Hans Christian Andersen's tale The Emperor's New Clothes (1837). In the story, Patronio tells the Conde Lucanor about three charlatans who pretended to be excellent weavers and tell the king that they have the power to weave a cloth that only those of legitimate birth are able to see. The king immediately commissions them to make this fabric: "[...] pues por aquel medio sabría quiénes eran hijos verdaderos de sus padres y quiénes no, para, de esta manera, quedarse él con sus bienes, porque los moros no heredan a sus padres si no son verdaderamente sus hijos."783 He installs them in one of the palace workshops and showers them with gold, silver, and silk. The 'weavers,' who of course are only pretending to be working on the cloth, describe it, however, in great detail to anyone who comes to 'take a look' at their 'work.' No one dares to say that they cannot see any fabric, for fear of being dishonored. The king is eventually dressed in the 'garments' made out of the magic cloth and appears before his entire people. Assuming that only he is unable to see the clothes, but that they are perfectly visible to those around him, he does not dare to trust, or to express, what his senses are telling him. It is only when a lowly groom, who in his own opinion "[...] no tenía honra que perder,"784 breaks the silence and declares out loud that the king is naked that this is gradually accepted as truth and the fraud revealed. In the meantime, the perpetrators have already fled with their ill-gotten gains.

Whether Cervantes was in fact inspired by this specific story is a question that has yet to be answered conclusively. If so, it must be noted that he not

782 Cf. (in a modernized version) Juan Manuel, El Conde Lucanor, ed. Juan Vicedo, 2nd ed., Alicante 1997, pp. 129-131 (“Cuento XXXII. Lo que sucedió a un rey con los burladores que hicieron el paño"). In the Sevillian print it is in the seventh chapter ("Cap. 7. De lo que acontescio a vn rey con tres hombres burladores,” in: Juan Manuel, El Conde Lucanor, Sevilla 1575, fols. 20r-22r). Other possible sources - the fraud unfolds here on the basis of an "invisible painting' - include among others Till Eulenspiegel (27th Story, 'How Eulenspiegel became a painter for the Landgrave of Hesse and told him that bastards could not see the painting') and Juan de Timoneda's collection of narratives and anecdotes Buen aviso y portacuentos (1564; 'Cuento XLIX'). (Cf. Asensio, Itinerario del entremés [cf. note 779], pp. 108 f.; Marcel Bataillon, "Ulenspiegel y el Retablo de las maravillas de Cervantes" [1957], in: Marcel Bataillon, Varia lección de clásicos españoles, Madrid 1974, pp. 260-267; Kenworthy, The Entremeses of Cervantes [cf. note 779], pp. 88 f.; Isaías Lerner, "Notas para el Entremés del Retablo de las maravillas: fuente y recreación,” in: Hugo W. Cowes [ed.], Estudios de literatura española ofrecidos a Marcos A. Morínigo, Madrid 1971, pp. 37-55, here pp. 37-44; Mauricio Molho, Cervantes: Raíces folklóricas, Madrid 1976, pp. 49-90. For an entremés, sometimes erroneously considered a possible source, entitled Los tejedores, see below notes $846 \mathrm{f}$.).

783 Juan Manuel, El Conde Lucanor (cf. note 782), p. 129.

784 P. 131. 
only transforms the narration, with its interplay between deception and reality, into performance, but also transforms the characters and content of the 'legend' into the specifically Spanish context of his time.

In El retablo de las maravillas two trickster-puppeteers and their musicianaccomplice arrive at a Spanish village and perform their 'retable of marvels,' as they call it, in front of the town dignitaries; in reality, however, there is no show, no scenery, no script, no performing figures, there is nothing to be seen. The townspeople are told that only those of impeccable ancestry can see the show of wonders, i.e. those born in wedlock and those, and here is precisely the relevant difference compared to The Emperor's New Clothes, who are of 'pure blood' (limpieza de sangre, i.e. 'Old Christians' as opposed to the socalled 'New Christians' who are descended from Jews or Muslims). They therefore adamantly 'see' everything they are told is being enacted before them. When a quartermaster appears announcing the imminent arrival of a troop of soldiers looking for accommodation in the village, the villagers interpret this as also part of the play. The quartermaster declares that they are insane saying that there is nothing there. He is then attacked by the villagers, who accuse him of being a Jew because he cannot see the show. The play ends in a chaotic excess of violence, with the two swindlers triumphantly sneaking off to work their scam in the next town.

The hybrid nature of the play is already apparent in the preconditions for 'seeing' the show: on the one hand, the subject of illegitimate birth, with its sexual connotations, is typical of the comic genre; limpieza de sangre, on the other hand, was an ideological, political, and religious issue that was not usually the subject of comedy, and the way in which the play explores this theme, both ironically and critically, adds to it a serious dimension.

Before proceeding to a detailed examination of the plot and an analysis of Cervantes' drama, particularly with regard to the interplay of illusion and reality and to skepticism, it is important to elucidate on the historical context in which the play is situated. ${ }^{785}$

785 The basis of this sketch are the following studies and presentations: Albert A. Sicroff/Yom Tov Assis, art. "Limpieza de Sangre," in: Encyclopaedia Judaica, ed. Michael Berenbaum and Fred Skolnik, 22 vols., 2nd ed., Detroit, MI 2007, vol. 13, pp. 25-26; Cecil Roth/Yom Tov Assis, art. "Inquisition," in: Encyclopaedia Judaica, vol. 9, pp. 790-804; Benzion Netanyahu, The Origins of the Inquisition in Fifteenth Century Spain, 2nd ed., New York 2001; Max Sebastián Hering Torres, Rassismus in der Vormoderne: Die "Reinheit des Blutes" im Spanien der Frühen Neuzeit, Frankfurt am Main/New York 2006; David Nirenberg, Anti-Judaism: The Western Tradition, New York 2013, pp. 217-245; Yovel, The Other Within (cf. note 1), pp. 139-186. 
The estatutos de limpieza de sangre ('purity of blood statutes') were established in 1483 by the Inquisitor Tomás de Torquemada. This Early Modern religiously justified racist legislation of exclusion was based on the idea that faith is 'transmitted biologically,' meaning that conversion could never result in the sincere acceptance of the Christian faith. Thus, despite the forced conversion of tens of thousands of Jews and Muslims in Spain, Torquemada was able to preserve a distinction between the 'Old Christians of pure blood,' allegedly descendants of the Goths, and the descendants of the recently converted 'New Christians.' The statutes denied New Christians access to higher education and secular and religious offices. An individual could only enroll in a university if he could provide evidence of 'pure ancestry.' The 15th century saw numerous outbreaks of violence against converts in the Iberian Peninsula and several attempts made on a local level to introduce laws intended to deprive the cristianos nuevos of their rights. King Henry IV's approval in 1468 of a statute excluding conversos from all public offices in the cities of Ciudad Real and Toledo enabled this, initially local, legislation to spread throughout the Iberian Peninsula. The genealogical argument was of course an instrument of power politics, as the New Christians were once again deprived of the equal status they had gained with their conversion to Christianity.

The situation continued for hundreds of years. Spain in the 16th and 17th centuries was a society fixated on blood and lineage. Social advancement or even participation in society were only possible with genealogical proof of one's 'purity of blood. ${ }^{786}$ Even the mere utterance of suspicion that someone was of Jewish descent had far-reaching, and often devastating, consequences. The fear of social exclusion and persecution by the Inquisition, directed primarily against judaizantes ('Judaizing New Christians'), was ubiquitous. It was a society characterized by constant observation and mutual surveillance. A dislike of pork (pig is a food that Jews and Muslims consider unclean and therefore do not eat), a suspected avoidance of work on Saturdays (the Jewish Sabbath, as opposed to Sunday, the Christian Sabbath) or bathing on a Friday (the Jewish Sabbath began Friday evening so bathing on Friday was considered a sign of preparing for the Sabbath) all constituted suspicious behavior that cast doubt on the purity of one's Christian blood and left one open to denunciation. This in turn meant torture, financial ruin, and potential, if not certain, death at the hands of the Inquisition.

786 The concept of limpieza de sangre lasted well into the 19th century, as attested to by the fact that as late as 1860 proof of 'blood purity' was still a requirement for admission to the Military Academy, when it was then legally abolished. The Office of the Inquisition in Spain was established in 1478 and only disbanded in 1834. 
El entremés del Retablo de las maravillas opens with the appearance of Chirinos and Chanfalla, a pair of swindlers, who discuss the scam that they are planning. Chanfalla (a man) exhorts Chirinos (a woman) to pay close attention to his instructions, especially those regarding their new hoax, so that it could be as successful as their previous scam ("CHANFALlA: No se te pasen de la memoria, Chirinos, mis advertimientos, principalmente los que te he dado para este nuevo embuste, que ha de salir tan a luz como el pasado del llovista”). ${ }^{787}$ Chirinos assures him of her reliability, saying: "[...] lo que en mí fuere tenlo como de molde; que tanta memoria tengo como entendimiento, a quien se junta una voluntad de acertar a satisfacerte, que excede a las demás potencias” (p. 216). She uses the term memoria mentioned by Chanfalla and puts it into the context of the three faculties of the soul (potencias) of the anima rationalis: intellect (entendimiento), will (voluntad), and memory (memoria). Thus, in order to show that she is perfectly equipped to take part in the upcoming deception, she makes use of a terminology that is taken from the realm of theology and ethical philosophy. ${ }^{788}$ She ends by declaring that her 'will' to satisfy Chanfalla is the 'power of the soul' that is most effective of all ('una voluntad de acertar a satisfacerte, que excede a las demás potencias'). It should be noted that such a statement is one of the many instances in which Cervantes expresses his dissonant position towards the strict Counter-Reformation orthodoxy. According to the Tridentine doctrine, reason dominates will, whereas Protestant thought held the inverse to be true. The latter, via the presence of Augustian and Erasmian thinking, remained even in Counter-Reformation Spain hiddenly an issue of discussion. ${ }^{789}$

787 The text is quoted from: Miguel de Cervantes Saavedra, Entremés del Retablo de las maravillas, in: Miguel de Cervantes, Entremeses, ed. Nicholas Spadaccini, 19th ed., Madrid 2009 (1st ed. 1982), pp. 215-236, here p. 215; Page references are given in the following in the running text. The nature of Chanfalla's 'fraud with the rainmaker' ("embuste [...] del llovista") is not clear from the text. In research, reference is made to an anecdote known at the time, dealing with the burla of a poor student who elicited money from peasants by making them believe that he had the ability to produce rain (first: Maxime Chevalier, "'El embuste de llovista' [Cervantes, El retablo de las maravillas],” Bulletin Hispanique 78 [1976], pp. 97 f.).

788 In Augustine, for example, the mental faculties memoria, intelligentia, and voluntas are the human image of the Trinity (cf. Augustinus, De trinitate X, 11, 17-18 [used edition: Aurelius Augustinus, De trinitate: (Books VIII-XI, XIV-XV, appendix: book V) (Latin-German), ed. and trans. Johann Kreuzer, Hamburg 2001, pp. 120-127]).

789 Regarding the Tridentine conception (reason is above the will) cf. Thomas Aquinas, Summa theologica $\mathrm{I}^{\mathrm{a}}$ q. 82 a. 3; on the powers of the soul in general, cf. $\mathrm{I}^{\mathrm{a}}$ q. 77-83 (Aquinas, Summa [Latin] [cf. note 347], vol. 6 [1937], pp. 86-249, esp. pp. 222-225; Aquinas, Summa [English] [cf. note 347], vol. 1, pp. 382-421, esp. pp. 414 f.). The allegorical and dramatic form of the counterreformatory position in Calderón's auto sacramental La vida es sueño (see chap. 3.2) should also be noted in this context. For the Protestant view of the weakness of human reason, see Luther's 
Chirinos then asks Chanfalla why they had taken the young Rabelin with them, and whether it would not be better to carry out their project alone. Chanfalla explains that they need Rabelin to play music during the breaks between the appearances of the characters of the 'Show of Wonders': "Habíamosle [Rabelín] menester como el pan de la boca, para tocar en los espacios que tardaren en salir las figuras del Retablo de las Maravillas” (p. 216). This is the first reference to the "Retablo de las maravillas" of the title, but it does not explain to the readers/spectators exactly what this "nuevo embuste" is going to be. Again taking up and playing on the last word in Chanfalla's dialogue, Chirinos remarks that it would be a miracle (maravilla) if the villagers do not stone them because of Rabelin, for never before had she met such an 'unfortunate little creature' ("Maravilla será si no nos apedrean por solo el Rabelín; porque tan desventurada criaturilla no la he visto en todos los días de mi vida” p. 216). ${ }^{790}$ Rabelín arrives immediately after this statement and asks Chanfalla what there is to do in this place, because he is dying to show him that he will not regret bringing him along, and the two (Chirinos and Chanfalla) proceed to ridicule Rabelín's size (and his musical abilities):

RABELÍN: ¿Hase de hacer algo en este pueblo, señor Autor? Que ya me muero porque vuesa merced vea que no me tomó a carga cerrada.

CHIRINos: Cuatro cuerpos de los vuestros no harán un tercio, cuanto más una carga. Si no sois más gran músico que grande, medrados estamos.

RABELÍN: Ello dirá; que en verdad que me han escrito para entrar en una compañía de partes, por chico que soy.

CHANFAlLa: Si os han de dar la parte a medida del cuerpo, casi será invisible. (p. 217 f.)

repeated comparison as the 'whore of the devil' (cf. “[... .] des Teuffels Braut Ratio, die schöne Metze [...] [Ratio] ist die höchste Hure, die der Teuffel hat [...]" [D. Martin Luthers Werke (cf. note 592), sect. 1: Schriften, 73 vols., vol. 51 (1914), p. 126, 29-32 and passim ("Predigt am 2. Sonntag nach Epiphaniä [17. Januar 1546]” [pp. 123-134])]). For the Erasmism in Spain, cf. the basic study of Marcel Bataillon, Érasme et l'Espagne, ed. Daniel Devoto and Charles Amiel, 3 vols., Geneva 1991 (1st ed. Paris 1937: Érasme et l'Espagne: Recherches sur l'histoire spirituelle du XVIe siècle).

790 Rabelin's name is part of the comedy, as it is a diminutive derived from the word rabel, which is the name of a bow-stringed instrument, a precursor to the violin, but also crude slang for 'buttocks' (cf. the entry in Diccionario de Autoridades: "RABEL. s. m. Instrumento músico pastoríl. Es pequeño, de hechura como la del laúd. Cómponese de tres cuerdas solas, que se tocan con arco, y forman un sonido mui alto y agudo. [. . .] RABEL. Festiva y familiarmente se suele llamar al trasero, con especialidad hablando con los muchachos" [RAE, Diccionario de Autoridades (cf. note 604), vol. 5 (1737), p. 478a]). 
Riffing off of Rabelin's use of the expression "a carga cerrada"791 Chirinos embarks on an extended play on words, using the word carga, meaning a mercantile unit of measurement, which in English is roughly translated as: cargo, load, bundle, or bale. He was so small that even four of him would not be enough to fill up even 'un tercio' - i.e. one half of a $\operatorname{carga}^{792}$ - let alone a whole one. Cuerpo, tercio, and carga are also, however, terms used in the military. ${ }^{793}$ Using the double meaning of cuerpo as both human body and military unit, they joke that even four 'units' would not be enough to form an infantry regiment (tercio) together, let alone be sufficient to carry out an attack (carga). If he was not a bigger musician than he was tall, that is, if Rabelín's musical skills had been as limited as his body was small, Chirinos continues, they would be finished. When Rabelín replies that small as he is, he was still accepted into an acting company (compañia de partes), Chanfalla also begins to mock him, saying that if the share of revenue were measured in relation to the height of the actors, Rabelin's would be almost invisible. As opposed to the compañia de autor, where the actors were paid a fixed salary, in a compañia de partes the actors were partners who shared profits and risks, and any money left after the deduction of expenses was distributed proportionately among them. But Chanfalla's statement also refers to parte in the sense of part or role: if one were to give Rabelín a role made to measure, it would have to be almost invisible.

The cleverness and eloquence of the two burladores Chanfalla and Chirinos, are immediately apparent from these first two opening scenes. Obviously reaching their destination, Chanfalla recognizes the oncoming group of men as "el Gobernador y los Alcaldes," the governor and the councilors of the small town, and declares that Chirinos should sharpen her tongue on the sharpening stone of flattery, but not become too sharp: "ChANFALLA: Chirinos, poco a poco estamos ya en el pueblo, y éstos que aquí vienen deben de ser, como lo son sin duda, el Gobernador y los Alcaldes. Salgámosles al encuentro, y date un filo a la lengua en la piedra de la adulación; pero no despuntes de aguda” (p. 218).

791 In English, for example, this would roughly correspond to the phrase 'lock, stock, and barrel.' In Covarrubias it says: “Carga cerrada, lo que se compra, o toma sin saber si es bueno, o malo” (Covarrubias, Tesoro [cf. note 779], Primera Parte, fol. 202r).

792 Cf. "Tercio, vale la mitad de vna carga que se lleua a lomo" (Covarrubias, Tesoro [cf. note 779], Segunda Parte, fol. 186r).

793 In the 16th and 17th centuries, tercio was the name given to an infantry regiment of the Spanish army, carga means in the military context not only (ammunition) charge, but likewise 'attack' ( a la carga! - 'Attack!'), cuerpo, in English 'corps,' denotes a certain unit of soldiers. 
The gobernador (governor), the alcalde (mayor) Benito Repollo, the regidor (councilor) Juan Castrado, and the escribano (scribe) Pedro Capacho now enter the scene. Chanfalla behaves submissively and asks which of the gentlemen before him is the governor. When the Gobernador identifies himself and asks Chanfalla what he wants, the latter answers, ironically: "A tener yo dos onzas de entendimiento, hubiera echado de ver que esa peripatética y anchurosa presencia no podía ser de otro que del dignísimo Gobernador deste honrado pueblo, que, con venirlo a ser de las Algarrobillas, lo deseche vuesa merced" (p. 218). In view of such a 'peripatetic and space-filling presence' ('esa peripatética y anchurosa presencia'), Chanfalla explains, he should have recognized immediately that this was none other than the venerable governor of this 'honorable village.' Peripatein means 'to walk about' and Chanfalla is clearly referring to the fact that the Gobernador, accompanied by the other local authorities, is apparently on a 'walk' through the village. Peripatético is also a word used to describe an Aristotelian, a name that originated from the Peripatos, a covered walkway in the Lykeion-Gymnasion. It is very unlikely, however, that Chanfalla's intention is to actually classify the governor as an Aristotelian, especially since the term was also a colloquialism for a (sometimes ridiculous) 'odd person,' and further, the nominalized adjective in its feminine form was often used as a euphemism for prostitute. This wordplay, with its double and even triple entendres, highlights clearly how the play as a whole not only orchestrates, in a playful and comic manner, the idea of isosthenia on the level of the plot itself but in fact also transfers it to the semiotic level of linguistic signs as well. Many of the characters' statements can be interpreted in multiple ways, and there is no reliable agency in the play that enables the reader/ viewer to determine which of these meanings is in fact the one intended. For example, consider the second adjective used to describe the Gobernador's appearance, anchurosa. This can be understood at first blush in the sense of a 'proud, impressive appearance' that characterizes his personality, but of course also refers to his physical appearance, i.e. that he is quite fat. ${ }^{794}$ When

794 With regards to the second part of Chanfalla's sentence ("que, con vernirlo [Gobernador] a ser de las Algarrobillas, lo deseche vuestra merced" [If Your Grace is made Governor of Algarrobillas, reject it (the office)], research has always pointed out that Las Algarrobillas (or Garrovillas) was located in Extremadura, famous at that time for its ham (jamón ibérico). One possible reading would be that Chanfalla insinuates ironically that the Gobernador and his village were so 'honorable' that even should he be offered the post of governor in the (so-called 'old Christian') town of Algarrobillas this would be beneath him and he should turn it down. According to another possible reading, what he should be rejecting is his current office. The fact that 'las Algarrobillas' itself is the place of the entremés' action does not seem to me to 
Chanfalla calls the place honrado, he is voicing what will be the central theme of play, namely an understanding of honor linked exclusively to 'bloodline' and descent (which in turn is defined by the 'right' religious affiliation). This is subsequently established ironically by Chirinos. When the Gobernador asks again what Chanfalla is looking for and addresses him as "hombre honrado" (p. 219), Chirinos remarks: "Honrados días viva vuesa merced, que así nos honra. En fin, la encina da bellotas; el pero, peras; la parra, uvas, y el honrado, honra, sin poder hacer otra cosa” (p. 219; 'May Your Grace spend honorable days, thus we too are honored. It is like this: the oak gives acorns, the pear tree pears, the vine grapes, and the honorable man honor, without anything else being possible for them to do'). ${ }^{795}$ Apparently impressed by Chirinos' - supposed - rhetorical skill, the mayor Benito Repollo, classifies it as "[s]entencia ciceronianca [sic], sin quitar ni poner un punto” (p. 219). His mispronunciation of the adjective derived from Cicero, the name of a Roman rhetorician and philosopher, is immediately corrected by the scribe Pedro Capacho: "Ciceroniana quiso decir el señor alcalde Benito Repollo” (p. 219; italics in the original), whereupon the former states that he simply always wanted to say only the best, with little success ("BENITO: Siempre quiero decir lo que es mejor, sino que las más veces no acierto” p. 219). This is followed by the Gobernador asking, for the third time, what Chanfalla and Chirinos were looking for. Chanfalla introduces himself: "Yo, señores míos, soy Montiel, el que trae el Retablo de las Maravillas. Hanme enviado a llamar de la corte los señores cofrades de los hospitales, porque no hay autor de comedias en ella, y perecen los hospitales, y con mi ida se remediará todo" (p. 219). Chanfalla introduces himself as Montiel, an 'autor de comedias,' director of the 'Retable Theater of Marvels,' and so renown that he had been called to Madrid to come to the financial rescue of hospitals run by lay brothers, as there was no 'producer of plays' to be found (these brotherhoods derived a significant portion of their income from the corrales de comedia they maintained). ${ }^{796}$ It should be noted that the name

emerge from the sentence. The 'pueblo honrado' where Cervantes situates his satire on the obsession with limpieza de sangre has no explicit name.

795 Immediately before: "CHIRINOS: En vida de la señora y de los señoritos, si es que el señor Gobernador los tiene. CAPACHO: No es casado el señor Gobernador. CHIRINOS: Para cuando lo sea; que no se perderá nada. GOBERNADOR: Y bien, ¿qué es lo que queréis, hombre honrado?” (pp. 218 f.).

796 An editorial comment of the publisher of the edition used here (as well as in most other modern editions) notes a possible historical reference: On the one hand there was a lack of autores de comedias in Madrid's corral stages due to several deaths in 1610, and on the other hand the lay brotherhoods had also initiated puppet theater performances in the corrales due to financial constraints. The former, however (as already noted by Adolfo Bonilla) seems 
of the 'role' that Chanfalla now takes in the context of the retablo performance references El coloquio de los perros [The Colloquy of the Dogs], the famous final novel in Cervantes' Exemplary Novels. This text (especially in combination with the Novela del Casamiento engañoso [Novel of the Deceitful Marriage] that frames it) has several aspects that seem to parallel the drama being discussed here, especially with regard to issues of seeming and being, fiction/ imagination and reality. In the novela's central episode the witch Cañizares calls the picaro-dog Berganza" ${ }^{797}$ "Montiel" because she believes he is one of the two children of her former companion Montiela who at birth were transformed into dogs by 'la Camacha de Montilla,' another sorceress. By calling himself Montiel, 'el que trae el Retablo de las Maravillas,' Chanfalla is thus being associated with the realm of magic, ${ }^{798}$ or, to put it into the skeptical setting: the status of being of the figure: human, dog, or creature of witchcraft, is playful-ironically ambiguous.

When asked by the Gobernador what he means by Retablo de las Maravillas Chanfalla explains: because of the wondrous things performed and shown, their traveling theater was called the 'Retable of Marvels,' that the retablo ${ }^{799}$ itself was manufactured and created by the sage Tontonelo under such latitudes, orbits, celestial bodies, and stars, and with such references, features, and observations that no one can see the things shown on it if they belonged in any way to the 'race of baptized Jews' or were not born and conceived by his parents in legitimate marriage. Whoever was 'infected by these two so common diseases' would have to abandon the hope of being able to see the things never seen or heard before that were there presented:

unlikely, since there were quite a number of autores and only Nicolás de los Ríos is known to have died during this period (cf. Miguel de Cervantes, Entremeses, ed. Adolfo Bonilla y San Martín, Madrid 1916, p. 226 f. [note 186]). This is precisely the actor/director into whom Cervantes, in his comedia Pedro de Urdemalas, has his protagonist transformed.

797 Cf. Miguel de Cervantes, El coloquio de los perros, in: Miguel de Cervantes, Novelas ejemplares, ed. Harry Sieber, 2 vols., Madrid 1980, vol. 2 (17th ed. 1997), pp. 297-359, here pp. 334 f. 798 It should be mentioned that this already includes a satirical-critical dimension with regard to the intertextual reference. See, e.g., the commentary by Cipión on Berganza's story, after conceding that the 'spell' mentioned by Cañizares, with which they could allegedly be turned into human beings, is not effective either in allegorical interpretation nor in the literal sense: “[...] la Camacha fue burladora falsa, y la Cañizares embustera, y la Montiela tonta, maliciosa y bellaca, con perdón sea dicho, si acaso es nuestra madre, de entrambos o tuya, que yo no la quiero tener por madre" (p. 347).

799 The term retablo will be discussed in detail below (see pp. $351 \mathrm{ff}$.). It should be clarified at this point that the Spanish word retablo means puppet show or stage (and an altarpiece, retable, reredos). 
Chanfalla: Por las maravillosas cosas que en él se enseñan y muestran, viene a ser llamado Retablo de las Maravillas; el cual fabricó y compuso el sabio Tontonelo debajo de tales paralelos, rumbos, astros y estrellas, con tales puntos, caracteres y observaciones, que ninguno puede ver las cosas que en él se muestran, que tenga alguna raza de confeso, o no sea habido y procreado de sus padres de legítimo matrimonio; y el que fuere contagiado destas dos tan usadas enfermedades, despídase de ver las cosas, jamás vistas ni oídas, de mi retablo.

Legitimate birth and limpieza de sangre are set as prerequisites to seeing the retablo. At the same time, this racist discourse of exclusion is also undermined and ridiculed in the very name of its 'inventor,' a scholar named Tontonelo, because the word tonto means stupid, silly, and dumb. Benito, the mayor (who the audience knows by now is an ignorant person), notes that he now finds that there are new things to see in the world every day, and asks again who created the 'marvelous retable.' Chirinos answers that his name was Tontonelo of Tontonela who was a man whose beard was said to have reached to his belt. To this Benito replies - entirely missing the comic oxymoron - that men with long beards were usually profoundly learned. ${ }^{800}$

It is immediately decided that the performance will take place that very evening. The Gobernador further instructs the regidor Juan Castrado that, if he agrees, he should marry off his daughter Juana Castrada (whose godfather the Gobernador was) so that the show could be staged at his house for the entertainment of the wedding guests. Juan Castrado agrees, replying (exposing his submissiveness) that he was at the Gobernador's service and would always endorse his opinion, even if there was something standing against it ("aunque haya cosa en contrario"). ${ }^{801}$ Chirinos again takes a phrase said by a different character and twists it for her own purposes, saying that what 'stands against it' is that they would not get to see the show at all if they (Chanfalla and Chirinos) were not paid in advance for their work ("CHIRINOs: La cosa que hay en contrario es que, si no se nos paga primero nuestro trabajo, así verán las

800 "BENITO: Ahora echo de ver que cada día se ven en el mundo cosas nuevas. ¡Y qué! ¿Se llamaba Tontonelo el sabio que el Retablo compuso? CHIRINOS: Tontonelo se llamaba, nacido en la ciudad de Tontonela; hombre de quien hay fama que le llegaba la barba a la cintura. BENITO: Por la mayor parte, los hombres de grandes barbas son sabihondos” (p. 220). However, Benito's brief comment and seemingly satisfyingly answered question are the only commentary on the 'miracle-retable' description.

801 "GOBERNADOR: Señor regidor Juan Castrado, yo determino, debajo de su buen parecer, que esta noche se despose la señora Teresa [sic.] Castrada, su hija, de quien yo soy padrino, y, en regocijo de la fiesta, quiero que el señor Montiel muestre en vuestra casa su Retablo. JUAN: Eso tengo yo por servir al señor Gobernador, con cuyo parecer me convengo, entablo y arrimo, aunque haya otra cosa en contrario" (pp. 220 f.). 
figuras como por el cerro de Úbeda” p. 221). For, she says, if the whole village came to Juan Castrado's house that evening to see the show, no one would bother coming the following day. Therefore, it was only fair to pay them upfront: "No, señores; no, señores; ante omnia nos han de pagar lo que fuere justo” (p. 221). Benito Repollo's reply brings into focus the gap between the eloquent picaro-autores and the primarily uneducated and unintelligent councilors, when he misunderstands the Latin expression used by Chirinos and, thinking it is a name, says that there was neither an "Antona" nor an "Antoño" to pay them, but that the gentleman Juan Castrado would give them a decent fee, and if not, then the village council would pay. ${ }^{802}$ The scribe Pedro Capacho, who knows Latin, again corrects him: “CAPACHO: ¡Pecador de mí, señor Benito Repollo, y qué lejos da del blanco! No dice la señora Autora que pague ninguna Antona, sino que le paguen adelantado y ante todas cosas, que eso quiere decir ante omnia" (p. 221). Benito replies that if one spoke to him in the proper way ("a derechos," i.e. 'in Spanish'), he would also understand things correctly and that although Capacho, who was "leído y escribido" ('literate in reading and writing'), could probably understand "esas algarabías de Allende," he Benito could not ("BENito: Mirad, escribano Pedro Capacho, haced vos que me hablen a derechas, que yo entenderé a pie llano. Vos, que sois leído y escribido, podéis entender esas algarabías de allende, que yo no” pp. $221 \mathrm{f}$.). Benito reacts to Capacho's correction offensively, using his ignorance as an expression of contempt for the 'non-Christians' and proof of his own 'Old Christian' identity. In line with this cristiano viejo ideology he also casts doubt on the 'purity' of Capacho's heritage by accusing him of being educated and describing him as someone who - in contrast to himself - was able to understand 'esas algarabías de allende,' 'this distant, Arabic-sounding stuttering., Juan Castrado is willing to pay Chanfalla half a dozen ducados in advance and make sure that no other people from the village enter his house in the evening.

802 "BENITO: Señora Autora, aquí no os ha de pagar ninguna Antona, ni ningún Antoño; el señor regidor Juan Castrado os pagará más que honradamente, y si no, el Concejo. ¡Bien conocéis el lugar, por cierto! Aquí, hermana, no aguardamos a que ninguna Antona pague por nosotros" (p. 221).

803 In the proverb collection published by Gonzalo Correas in 1627, one reads: "Algarabía de allende, que el que la habla no la entiende. 'Algarabía de allende' se dice por lo que no se entiende y razón disparatada” (Gonzalo Correas, Vocabulario de refranes y frases proverbiales [1627], ed. Miguel Mir, 2nd ed., Madrid 1924 [1st ed. 1906], p. 30). Benito’s statement reflects a common stereotype regarding the 'erudition' of the so-called 'New Christians.' His statement highlights the ridiculousness of this stereotype and ironically disputes the ideological concept on which the argument is based. 
Chanfalla agrees to the offer. Castrado then asks Chanfalla to accompany him to his house so that he can give him the money and show him where to set up. As they leave, Chanfalla again admonishes those present not to forget the qualifications that those who are brave enough to come see the 'marvelous retable' must have ("ChAnfalla: [...] y no se les pase de las mientes las calidades que han de tener los que se atrevieren a mirar el maravilloso Retablo” p. 222). It is not by chance that Chanfalla mentions bravery, because during this period in Spain the dangers of being accused of having Jewish ancestry were quite severe. The serious import of the statement is comical-ironically broken (as befits the entremés genre) by the fact that, as has already been noted, those who are 'honorless' in the less harmful sense of being illegitimate are also not able to see the show. Since (as far we know today) it is possible that a large part of the rural peasant population of the time were illegitimate, it is clear how the spectators will later react to the void staged by the troupe. Benito has no trouble declaring that he himself could undergo this test with equanimity, since his father had been mayor. Furthermore, he says: “[. . .] cuatro dedos de enjundia de cristiano viejo rancioso tengo sobre los cuatro costados de mi linaje: ¡miren si veré el tal Retablo!” (p. 222; 'I have four finger breadths of fat from ancient Old Christian on all four sides of my lineage: I will certainly be able to see that retablo!'). By playing on the semantic fields of 'lineage' and 'meat,' Benito's declaration of his undoubtedly 'pure' origin is interwoven with a reference to a common assumption of the time that was used to identify so-called 'judaizantes' based solely on their refusal to eat pork. Hence the term enjundia means both 'animal fat' and 'strength, substance, and significance,' and rancioso means 'ancient' in the sense of 'old ancestry,' but also 'rancid and greasy,' while costado ('side') is both a term used in the context of genealogy, in the sense of 'line of kinship' (and los cuatro costados i.e. maternal and paternal grandparents), ${ }^{804}$ as well as, in its etymological sense, 'ribbed' (< Lat. COSTĀTUS), i.e., a 'piece of meat.' Pork is known to be quite fatty, so Christians of 'impure blood, according to this terminology, would not touch this 'fatty meat.' Once again the word play points to the ironic perspective that runs through the entremés, down to the level of semantics, as well as alluding to the racist conceptions of the period. The function of these allusions will be discussed further on.

804 Cf. "HIDALGO DE QUATRO COSTADOS. Es aquel que sus quatro avuelos fueron hidalgos de casa y solar conocido" (RAE, Diccionario de Autoridades [cf. note 604], vol. 4 [1734], p. 150b). 
The others present are immediately at great pains to emphasize that they too have no concerns about passing the test. Capacho replies to Benito that they will all be able to see the retablo. Juan Castrado points out that none of them are of base origin. ${ }^{805}$ The Gobernador notes (without explicit reference to an 'Old Christian origin' of his own) that as far as he is concerned all his fellow citizens fulfill the preconditions set by the actors ("Todo será menester, según voy viendo, señores Alcalde, Regidor y Escribano” p. 223). As Juan Castrado leaves with Chanfalla, he too is determined to tell the autor about his origins: "Vamos, Autor, y manos a la obra, que Juan Castrado me llamo, hijo de Antón Castrado y de Juana Macha; y no digo más en abono y seguro que podré ponerme cara a cara y a pie quedo delante del referido retablo” (p. 223). But this testimony of an 'impeccable origin' is also open to ridicule, with sexual innuendo again coming into play. Juan gives his parents' names as proof, but the name of his father, which he also bears, actually means 'castrated' or 'emasculated,' while his mother's name means 'male.' This type of irony is not limited to Juan Castrado but also appears in the names of other (speaking) characters, such as Repollo, Capacho, and later licenciado Gomecillos, Juana Castrada, and Teresa Repolla, which in the context of the theme of the play serves to underscore the ridiculousness of these characters. Chirinos responds to Castrado with the remark “ ¡Dios lo haga!” (p. 223), and the two depart.

Following this, the Gobernador asks the autora Chirinos which poets currently were the most famous in Madrid and had the best reputations, particularly among the so-called comedy writers. For he, too, says the Gobernador, was something of a poet and a supporter of acting. He knew his way around the comedy world and had written 22 new comedias one after the other without interruption. He only waited for a suitable time to travel to court to make half a dozen autores rich with them. ${ }^{806}$ Chirinos' reply can be read as a sharp allusion to the contemporary theater scene, particularly the overwhelming success of the plays written by Lope de Vega and his school. In this sense, she says, she hardly knew how to answer his question about the poetas because there were so many that they could obscure the sun, and all of them thought themselves famous, so that there was no use in enumerating them ("A lo que vuesa

805 "CAPACHO: Todos le pensamos ver, señor Benito Repollo. JUAN: No nacimos acá en las malvas, señor Pedro Capacho” (p. 222).

806 "GobernAdor: Señora Autora, ¿qué poetas se usan ahora en la corte, de fama y rumbo, especialmente de los llamados cómicos? Porque yo tengo mis puntas y collar de poeta, y pícome de la farándula y carátula. Veinte y dos comedias tengo, todas nuevas, que se veen las unas a las otras; y estoy aguardando coyuntura para ir a la corte y enriquecer con ellas media docena de autores" (p. 223). 
merced, señor Gobernador, me pregunta de los poetas, no le sabré responder; porque hay tantos que quitan el sol, y todos piensan que son famosos. [...] así no hay para qué nombrallos” pp. 223 f.). When Chirinos asks the Gobernador for his name and he replies that his name was "el Licenciado Gomecillos" (p. 224), she immediately pretends to recognize him as the author of the "famous coplas' "Lucifer estaba malo" and "Tómale mal de fuera." This the Gobernador firmly rejects, saying that evil tongues had pinned these poems on him, but he was by no means their author. He did, however, and he did not want to deny this, indeed write those coplas that dealt with the flooding in Seville. And he continues that if the poets were stealing from each other, he could boast that he had never stolen anything; may God help him with his verses and may steal whoever wanted (“[. . .] puesto que los poetas son ladrones unos de otros, nunca me precié de hurtar nada a nadie: con mis versos me ayude Dios, y hurte el que quisiere" p. 224). ${ }^{807}$ The conversation between Chirinos and the Gobernador, marked by satirical allusions to the literary scene of the day (a not uncommon feature in Cervantes' work) ${ }^{808}$ is interrupted by Chanfalla's return. Announcing that everything was now ready for the performance, he asked everyone to accompany him so that they could start the play. Chirinos asks her accomplice, again using a Latin phrasing, whether the money was already 'in their bag' (“¿Está ya el dinero in corbona?” p. 225). ${ }^{809}$ Chanfalla confirms this with the words: "Y aun entre las telas del corazón” (p. 225). When

807 "Chirinos: [...] Pero dígame vuesa merced, por su vida: ¿cómo es su buena gracia? ¿Cómo se llama? Gobernador: A mí, señora Autora, me llaman el Licenciado Gomecillos. Chirinos: ¡Válame Dios! ¡Y que vuesa merced es el señor Licenciado Gomecillos, el que compuso aquellas coplas tan famosas de Lucifer estaba malo y Tómale mal de fuera! GOBERNADOR: Malas lenguas hubo que me quisieron ahijar esas coplas, y así fueron mías como del Gran Turco. Las que yo compuse, y no lo quiero negar, fueron aquellas que trataron del diluvio de Sevilla; que, puesto que los poetas son ladrones unos de otros, nunca me precié de hurtar nada a nadie: con mis versos me ayude Dios, y hurte el que quisiere" (p. 224).

808 It should be noted that the thematic complex of 'origin' and 'ascription' is also applied here to the realm of poetry ('Malas lenguas hubo que me quisieron ahijar esas coplas', notes the Gobernador, further: 'los poetas son ladrones unos de otros').

809 The Latin term corbona used by Chirinos is used here in the sense of '(the money is) in קרבן the bag.' The term corbona appears in the biblical context. It goes back to the Hebrew (qorbān, 'offering') and refers to the temple treasury (but outside of the religious sphere, it simply meant jewelry or money chest). In the New Testament, the phrase 'in corbona' appears in $M t$ 27,6: "Principes autem sacerdotum, acceptis argenteis, dixerunt: Non licet eos mittere in corbonam: quia pretium sanguinis est”/'And the chief priests took the silver pieces, and said, It is not lawful for to put them into the treasury, because it is the price of blood' [my italics]). Judas had returned the 'thirty pieces of silver' he had received for the betrayal of Jesus, to the High Council and hanged himself. 
Chirinos warningly tells him that the Gobernador is a poet ("Pues doite por aviso, Chanfalla, que el Gobernador es poeta” p. 225), he replies that if so, she could already regard him as "engañado,” i.e., successfully deceived, since all people of this kind were unwary, gullible, and unsuspecting (“¿Poeta? ¡Cuerpo del mundo! Pues dale por engañado, porque todos los de humor semejante son [...] gente descuidada, crédula y no nada maliciosa” p. 225). Everyone leaves, excited to finally see the wonders ("BENITO: Vamos, Autor; que me saltan los pies por ver esas maravillas” p. 225).

The next scene takes place in the Castrado house, with the two (as the stage instruction states) labradoras Juana Castrada (Juan Castrado's daughter) in her wedding dress and Teresa Repolla (daughter of Benito Repollo) talking together. They make sure that they get a good seat and Juana reminds Teresa of the conditions that they have to fulfill in order to see the show of wonders, saying that she should be wary, otherwise it would be a great misfortune. Teresa responds that as the two were cousins, there was nothing more to say. She wished that she could be as certain of going to heaven as she was certain of seeing the show before her. By the life of her mother, she would tear out her eyes, if such a misfortune were to befall her. Juana admonishes her to be quiet, because the others were coming. ${ }^{810}$ Enter the other 'spectators,' that is, the Gobernador, Benito Repollo, the host Juan Castrado, Pedro Capacho, and "otra gente del pueblo" as well as the 'directors' Chanfalla, Chirinos, and the musician Rabelin. ${ }^{811}$ Chanfalla gives instructions for the performance. He asks everyone to take a seat, saying that the retablo (that is, the 'stage') should be put behind the "repostero" - in the literal sense a kind of wall hanging, which in the reality of the play is only a simple blanket (manta) that Chanfalla calls a curtain ${ }^{812}$ - where the "[a]utora," i.e. Chirinos, will sit, and he then tells Rabelín where to stand in the room ("Siéntense todos; el Retablo ha de estar

810 "CASTRADA: Aquí te puedes sentar, Teresa Repolla amiga, que tendremos el Retablo enfrente; y pues sabes las condiciones que han de tener los miradores del Retablo, no te descuides, que sería una gran desgracia. TERESA: Ya sabes, Juan Castrada, que soy tu prima, y no digo más. ¡Tan cierto tuviera yo el cielo como tengo cierto ver todo aquello que el Retablo mostrare! ¡Por el siglo de mi madre, que me sacase los mismos ojos de mi cara, si alguna desgracia me aconteciese! ¡Bonita soy yo para eso! CASTRADA: Sosiégate, prima; que toda la gente viene” (p. 225).

811 Stage direction: “(Entran el Gobernador, Benito Repollo, Juan Castrado, Pedro CaPacho, EL AUTOR [i.e. Chanfalla] y LA AUTORA [i.e. Chirinos], $y$ EL MúsiCo [i.e. Rabelín], $y$ otra gente del pueblo, $y$ Un SOBRINo de Benito, que ha de ser aquel gentil hombre que baila.)" (p. 226).

812 Cf. the entry in DRAE: "[repostero] 3. Paño cuadrado o rectangular, con emblemas heráldicos" (used edition: Real Academia Española, Diccionario de la lengua española, 22nd ed. Madrid 2001 [1st ed. 1780]); in the last stage direction it says: "y la CHIRINos descuelga la manta” (p. 236), also: "BENITO: [to Rabelín] [...] ¡Métete tras la manta [...]!” (p. 230); cf. the 
detrás deste repostero, y la Autora también, y aquí el músico” p. 226). In this context it is interesting to look briefly at Covarrubias' entry on puppets, where he sets down the characteristics of a typical puppet theater performance:

TITERES, Ciertas figurillas que suelen traer los estrangeros en vnos retablos, que mostrando tan solamente el cuerpo dellos, los gouiernan como si ellos mesmos se mouiesen; y los maestros que estan dentro, detras de vn repostero y del castillo que tienen de madera, estan siluando con vnos pitos, que parece hablar las mesmas figuras, y el interprete que està aca fuera declara lo q[ue] quiere[n] dezir. Y porque el pito suena, ti, ti, se llamaron titeres [.. ..$^{813}$

Thus, in our play Chirinos takes on the role of the 'maestro[s] [...] detras de[l] [...] repostero,' a 'puppeteer without puppets' while Chanfalla is the interprete standing outside the stage and describing the events to the audience. ${ }^{814}$

As Chanfalla introduces Rabelín reference is again made to his small physical appearance and precarious musical ability, when Benito remarks: “¿Músico es éste? Métanle también detrás del repostero, que, a trueco de no velle, daré por bien empleado el no oílle” (p. 226). Hereupon, Chanfalla rebukes him, saying that he had no reason to be displeased because of the musician, after all, he was a good Christian and 'an Hidalgo of well-known ancestry' ("CHANFALLA: No tiene vuesa merced razón, señor alcalde Repollo, de descontentarse del músico, que en verdad que es muy buen cristiano y hidalgo de solar conocido" p. 226). The fact that, of all people, it is Rabelin, the small, not particularly handsome, destitute, untalented musician employed by scam artists who is called 'hidalgo de solar conocido' provides additional comic satire to the theme of honor in the play and is also a jab at the excessive preoccupation with honor that was so prevalent in Spain during this period. The Gobernador also interferes and notes that in order to be a good musician, one must certainly be equipped with 'qualities' (calidades) (“GOBERNADOR: ¡Calidades son bien necesarias para ser buen músico!” p. 226). Here again is a double meaning, because calidad means 'characteristic' or 'virtue' but refers not only to a person's abilities but also to their lineage, as another meaning for calidad is nobleza de linaje. Benito then interjects that Rabelín might well be from a good family ("[d]e solar"), but it's doubtful whether he was also a good musician ("mas de sonar, abrenuncio"). Rabelin defends himself: “¡Eso se merece el bellaco que se viene a sonar delante de ... !", and the mayor again: “¡Pues, por Dios, que hemos visto aquí sonar a otros músicos tan ... !” (p. 226). The Gobernador declares that the

above cited entry from Covarrubias, Tesoro de la lengua castellana on puppetry: the puppeteers are behind a 'repostero.'

813 Covarrubias, Tesoro (cf. note 779), Segunda Parte, fol. 45v.

814 Cf. this reference already in Kenworthy, The Entremeses of Cervantes (cf. note 779), p. 91. 
dispute between Rabelin and the alcalde is over, indicating its potential endlessness and insists that the performance should begin. ${ }^{815}$ Benito notes how few props had been brought along considering the announced dimensions of the play, whereupon Castrado suspects, relying on what Chanfalla had promised them, that everything was related to miracles ("BENITO: ¡Poca balumba trae este autor para tan gran Retablo. JuAN: Todo debe de ser de maravillas.” p. 227).

The 'play within the play' commences, with Chanfalla declaring: “¡Atención, señores, que comienzo!” (p. 227). The performance begins with a formulaic incantation similar to magic:

Chanfalla: ¡Oh tú, quien quiera que fuiste, que fabricaste este Retablo con tan maravilloso artificio, que alcanzó renombre de las Maravillas: por la virtud que en él se encierra, te conjuro, apremio y mando que luego incontinenti muestres a estos señores algunas de las tus maravillosas maravillas, para que se regocijen y tomen placer sin escándalo alguno!

(p. 227)

Chanfalla calls upon the creator of the Retablo de las Maravillas to show some of its wonders to those present for their entertainment and pleasure, without causing the slightest scandal. Immediately 'his request is answered,' as Chanfalla notes. Chanfalla begins to evoke the first scene by describing what he himself now 'sees' (and what the audience should also be able to see, provided that they were cristianos viejos and hijos legitimos). Taken a scene from the biblical story of Samson (Judges 16) Chanfalla describes the appearance of the brave Samson, who embraces the pillars of the pagan temple to tear it down and take revenge on his enemies. ${ }^{816}$ Chanfalla turns pleadingly to the

815 "GobERNADOR: Quédese esta razón en el de del señor Rabel y en el tan del Alcalde, que será proceder en infinito; y el señor Montiel comience su obra” (p. 227).

816 Samson, blinded and imprisoned by the Philistines, is taken out of the dungeon during festivities in honor of their god Dagon for the amusement of the people. Samson calls upon God to give his strength back to him and destroys the pillars of the temple, bringing the whole edifice down on him and the thousands of Philistines inside (cf. Jdg 16,22-30). Samson was betrayed by Delilah, his lover, who sold the secret of his strength (his long hair) to the Philistines. Delilah having cut his hair while he was sleeping, Samson was captured and blinded. Samson had lied to Delilah three times when she asked him to tell her the secret to his strength (saying first that he needed to be tied with seven fresh bowstrings, secondly tied with new, unused ropes, and thirdly if his seven curls were braided with a loom and his hair fastened to the floor with a stake). Only after she accuses him of not really loving and trusting her does he reveal his secret (Cf. Jdg 16,4-21). In the interpretation of Bruce W. Wardropper ("The Butt of the Satire in El retablo de las maravillas," Revista Cervantes 4:1 [1984], pp. 25-33) the Samson element is an implicit reference to the theme of betrayal. He interprets the entremés as a statement that the statutes of limpieza sangre by distinguishing between 'old' 
figure 'appearing' on the retablo stage, begging Samson to refrain from such a disaster, and not to crush and bury the many noble people gathered here:

Chanfalla: Ea, que ya veo que has otorgado mi petición, pues por aquella parte asoma la figura del valentísimo Sansón, abrazado con las colunas del templo para derriballe por el suelo y tomar venganza de sus enemigos. ¡Tente, valeroso caballero; tente, por la gracia de Dios Padre! ¡No hagas tal desaguisado, porque no cojas debajo y hagas tortilla tanta y tan noble gente como aquí se ha juntado!

(p. 227)

The permeability of the 'play within the play,' which transcends the boundaries of stage and audience, was first established by the tricksters' postulation that only certain people can see it. It is further expressed in the individual scenes 'enacted.' Chanfalla the 'director' mediates the action. What he marks as 'to be seen' is not an isolated stage show, but is, as he emphasizes here, linked to the 'real well-being' of the audience. In the scene of Samson the spectators are analogous to Samson's enemies, the Philistines, killed along with Samson in the temple when he brought it down around their heads. The action, or supposed action on stage, i.e., the images of the performance evoked by Chanfalla, are linked to those watching - the boundary is fluid, or rather is designated as such. The stage 'action' is given 'real' efficacy for the audience (in the sense that the 'rules' of the wonder show already presuppose a dependency between the space of the stage and the space of the audience). Chanfalla (ironically) refers to the 'noble attendees' and insinuates that the Samson appearing on stage is not tearing down a fictitious building, but can also bury them under the wreckage ('no cojas debajo y hagas tortilla tanta y tan noble gente como aquí se ha juntado!'). This is, of course, much influenced by comic exaggeration, as is clear, for example, from Chanfalla's use of the colloquial 'no hagas tortilla' ('do not crush and flatten [them] into omelets'). On a more serious note, the whole scene is ideologically charged by the story supposedly being enacted. The story of Samson is the idea of the heroic struggle of a servant of the one and true God against the idolaters. Those spectators who do not 'see' this run the risk of arousing a suspicion of not wanting to see it, that is, of themselves being idolaters. The irony of the use of the theme of Samson is of course that this Old Testament story is a reminder of how problematic the rigid separation of Christian and Jewish faith is, as crystallized in the concept of 'blood purity. ${ }^{, 817}$

and 'new' Christians, was a betrayal of the Christian religion ('limpieza de sangre' vs. 'limpieza de corazón').

817 Ruth Fine has pointed out how the Cervantine oeuvre specifically tries to break apart the preoccupation with the symbolic-semantic fields of 'Jewish' (lo judio), 'Hebrew' (lo hebreo) and 'New Christian' (lo converso) evident in the literature and extra-literary discourse of the 
The inner spectators immediately begin to refer to the 'events on the stage,' as narrated to them by Chanfalla. Benito addresses Samson directly and asks him to stop and spare him, not without commenting on the situation, however, that they were there for entertainment's sake, thus 'such an ending' would be against this ("BENITO: ¡Téngase, cuerpo de tal, conmigo! ¡Bueno sería que, en lugar de habernos venido a holgar, quedásemos aquí hechos plasta! ¡Téngase, señor Sansón, pesia a mis males, que se lo ruegan buenos!” p. 227). While Benito is referring directly to the stage action, the reaction of the other audience members relates to their perception of the stage events as such (and thus also implicitly to the prerequisites necessary to see them). Capacho asks Castrado whether he could see him, that is, Samson, who instantly and vehemently responds that he can ("CAPACHO: ¿Veisle vos, Castrado? JuAN: ¿Pues no le había de ver? ¿Tengo yo los ojos en el colodrillo?” p. 227). The Gobernador, on the other hand, in an aside (aparte) notes with astonishment that he cannot see anything at all, and reflects on the clash between this fact and what he knows to be true about his 'impeccable origin,' which should have guaranteed that he could see the show: “GoBERnADOR: [Aparte.] ¡Milagroso caso es éste! Así veo yo a Sansón ahora, como el Gran Turco. Pues en verdad que me tengo por legítimo y cristiano viejo” (p. 228). ${ }^{818}$ Suddenly Chirinos, who is standing

time (cf., e.g., Ruth Fine, "El entrecruzamiento de lo hebreo y lo converso en la obra de Cervantes: un encuentro singular," in: Ruth Fine/Santiago López Navia [eds.], Cervantes y las religiones: Actas del coloquio internacional de la Asociación de Cervantistas [Universidad Hebrea de Jerusalén, Israel, 19-21 de diciembre de 2005], Madrid 2008, pp. 435-451 [on El retablo de las maravillas, cf. pp. 444 f.] as well as Ruth Fine, Reescrituras bíblicas cervantinas, Madrid/Frankfurt am Main 2014 [on El retablo de las maravillas, cf. pp. 177-186]).

818 With regard to the apartes ('asides,' i.e. the text of a character spoken aside for viewers/ readers to hear rather than the others on stage), it should be noted that the explicit labeling of the corresponding (three) text passages as such ("[Aparte.]") constitutes an editorial supplement by the publisher of the edition used here, which is also used in most other modern editions. This first speaking aside (that is, the expression about not perceiving anything of what is suggested 'to be happening on stage'), however, is sometimes attributed not to the Gobernador, but to the scribe Pedro Capacho: For example, in the edition of the Ocho comedias y ocho entremeses of 1749 (Miguel de Cervantes, Comedias, y Entremeses ..., Con una Dissertacion, o Prologo sobre las Comedias de España [por Blas Nasarre], 2 vols., Madrid 1749, vol. 1, p. 300), in Adolfo Bonilla (Miguel de Cervantes, Entremeses, ed. A. Bonilla, Madrid 1916, p. 112), and in the Castalia edition by Eugenio Asensio (Miguel de Cervantes, Entremeses, ed. E. Asensio, Madrid 1971, p. 177). I agree, however, with the variant given in Spadaccini's edition. In my opinion, all three apartes are said by the Gobernador. In the editio princeps, the speaker's name for the above cited first aparte is "Co." (Cervantes, Ocho comedias, y ocho entremeses nvuevos, nunca representados, Madrid 1615, fol. 246r; consulted copy: Biblioteca Nacional de España, Sig. CERV.SEDÓ/8698). This is probably a misprint, 'C' instead of ' $G$ ' ('Go.' for 'Gobernador'); the Gobernador's speeches are always marked with the abbreviation 
behind the curtain, interrupts, shouting that a bull was running towards them: “¡Guárdate, hombre, que sale el mesmo toro que mató al ganapán en Salamanca! ¡Échate, hombre; échate, hombre; Dios te libre, Dios te libre!” (p. 228) and Chanfalla instructs everyone to throw themselves on the ground (“¡Échense todos, échense todos! ¡Húcho ho!, ¡húcho ho!, ¡húcho ho!”). This engenders much confusion, with the stage direction reading "(Échanse todos $y$ alborótanse.)" (p. 228). With this assertion that a wild bull was about to charge them, namely the bull who had killed 'the day laborer in Salamanca, 819 the Samson plot is abruptly interrupted and the next 'danger' immediately evoked. As happened previously, the audience's reactions follow instantly. Benito's remarks try to leave no doubt that he is actually seeing what the "theater directors" are narrating. He even describes the bull as being so ferocious as 'if it was possessed by the devil,' describing its coloring, and exclaiming that if he had not thrown himself to the ground, the bull would have taken him by the horns ("¡El diablo lleva en el cuerpo el torillo! Sus partes tiene de hosco y de bragado. Si no me tiendo, me lleva de vuelo” p. 228). Castrado then asks Chanfalla to make sure, as far as possible, that no more frightening characters appear, saying that this was not for his own sake, but for the girls present who had been terrified by the bull and had not a drop of blood left in their bodies. Castrada confirms her father's statement, adding that it would take her more than three days to recuperate, and that she had already seen herself impaled on the horns of the bull, which were as pointed as a shoemaker's awl. The subtext here is of course an obscene one, linked to the subject of marriage. This was a common element in the entremés. Castrado then notes that after all Castrada would not be his daughter if she could not see it; a statement that, taking into account the names of the speaker and the person addressed, ultimately caricatures itself.

\footnotetext{
"Go." with one exception: "Gouer." (fol. 246r). For the identification of the speaker Pedro Capacho there are the variants of full naming ("Capacho." appears three times) and the abbreviations "Capo.” (four times), “Capa.” (twice), and "Ca.” (three times); that the passage is also attributed to Capacho, would then be due to an interpretation of the typo as "Co." instead of 'Ca' (for 'Capacho'). It should be noted that the two following aparte passages are then clearly identified as speeches of the Gobernador (with the abbreviations "Gouer." [fol. 246r] and "Go." [fol. 246v]).

819 According to Mauricio Molho, this is an allusion to a historical event (“[ . . ] [el] torino salmantino de ocho años que mató al ganapán de Monleón [a place in the province of Salamanca] [...]" [Cervantes: Raíces folklóricas (cf. note 782), p. 206]); the commentaries and the secondary literature refer mostly to Molho's interpretation. In any case, the mention of the particular city of Salamanca is intended to refer to a real and well-known event.
} 
JuAN: Señor Autor, haga, si puede, que no salgan figuras que nos alboroten; y no lo digo por mí, sino por estas mochachas, que no les ha quedado gota de sangre en el cuerpo, de la ferocidad del toro.

CASTRADA: ¡Y cómo, padre! No pienso volver en mí en tres días; ya me vi en sus cuernos, que los tiene agudos como una lesna.

JUAN: No fueras tú mi hija, y no lo vieras.

(pp. 228 f.)

Subsequently, the Gobernador again reflects in an aside - thus repeating the previous structure - on the difference between his own perception and that of the other audience members. As he admits to himself (and to the viewers/readers), he can see nothing of what the rest of the audience claims to see, but for the sake of appearances he would have to say that he too could see the events on the stage: "GOBERNADOR: [Aparte.] Basta; que todos ven lo que yo no veo; pero al fin habré de decir que lo veo, por la negra honrilla" (p. 229). The Gobernador's confession that he will pretend to see something that he actually does not see for the sake of negra honrilla, is an ironic allusion, as is the play as a whole, to the concept of honor prevalent in the Spanish society of the period, with its obsessive focus on the importance of appearances that must be preserved at all cost. ${ }^{820}$

820 A prominent text of satirical-ironic reference to the concepts limpieza de sangre and honor that dominated Spanish society is the Lazarillo de Tormes, which appeared for the first time over sixty years before Cervantes' entremés (“[...] Lazarillo de Tormes deals not only with the religiously based apparatus of exclusion [...] but also with its secular equivalent, and in an indissoluble connection. The third tratado, in which Lazarillo serves an impoverished nobleman, deals explicitly with the sense of honor" [Zepp, An Early Self (cf. note 1), p. 80, cf. altogether: pp. 73-92]). In the escudero episode in the tractado tercero the first-person narrator says: " $\mathrm{iOh}$, Señor, y cuántos de aquestos debéis Vós tener por el mundo derramados, que padescen por la negra que llaman honra lo que por Vós no sufrirán!" (La vida de Lazarillo de Tormes y de sus fortunas y adversidades, ed. Francisco Rico, 15th ed., Madrid 2000 [1st ed. 1987], p. 84; my italics); to the discrepancy observed by Lázaro between appearance and reality in the life of this (third) master, the impoverished nobleman - he has neither an appropriate place to sleep nor sufficient food - who always endeavors to be seen as a believing Christian and an honorable nobleman, cf. for example, what is immediately preceding the previous quote: “¿Quién encontrará a aquel mi señor que no piense, según el contenido de sí lleva, haber anoche bien cenado y dormido en buena cama, y, aun agora es de mañana, no le cuenten por muy bien almorzado? [...] ¿A quién no engañará aquella buena disposición y razonable capa y sayo? ¿Y quién pensará que aquel gentil hombre se pasó aqer todo el día sin comer, con aquel mendrugo d pan ques u criado Lázaro trujo un día y una noche en arca de su seno, do no se le podía pegar mucha limpieza, y hoy, lavándose las manos y cara, a falta de paño de manos se hacía servir de la halda del sayo? Nadie, por cierto, lo sospechará" (pp. 83 f.) as well as: "Y súbese por la calle arriba con tan gentil semblante y continente, que quien no le conosciera pensara ser muy cercano pariente al Conde de Arcos, o a lo menos camarero que le daba de vestir” (p. 82). The 
The play shifts directly to the 'next scene.' Taking up the negra honrilla referred to by the Gobernador, the play parodies this over-focus on the 'right' heritage when Chirinos assures the audience that all the mice: white, spotted, speckled, and even blue, but after all they were all mice, now seen on stage were direct descendants of the mice from Noah's Ark: "CHIRINOS: Esa manada de ratones que allá va, deciende por línea recta de aquellos que se criaron en el arca de Noé; dellos son blancos, dellos albarazados, dellos jaspeados y dellos azules; y, finalmente, todos son ratones” (p. 229). Juana Castrada and Teresa Repolla 'panic' at the 'sight' of the many rodents. Teresa exclaims that if she was not being held, she would have jumped out of the window in fear and instructs her cousin to keep her skirts together to prevent getting bitten. She also embellishes on the narration saying that contrary to what Chirinos had said, it was more like thousands of mice rather than just a few. She even claims to feel a mouse climbing her leg. In response Benito says that lucky for him he is wearing gregüescos (Spanish breeches), so no mouse, no matter how small, would be able 'to enter' him.

CASTRADA: ¡Jesús!, ¡Ay de mí! ¡Ténganme, que me arrojaré por aquella ventana! ¿Ratones? ¡Desdichada! Amiga, apriétate las faldas, y mira no te muerdan; ¡Y monta que son pocos! ¡Por el siglo de mi abuela, que pasan de milenta!

REPOLLA: Yo sí soy la desdichada, porque se me entran sin reparo ninguno. Un ratón morenico me tiene asida de una rodilla. ¡Socorro venga del cielo, pues en la tierra me falta!

BENITO: Aun bien que tengo gregüescos: que no hay ratón que se me entre, por pequeño que sea.

Here too, besides the serious main concern: the denunciation of a literally understood 'blindness' by means of an ideological grid of perception, the obscene subtext is evident.

expression 'negra honra' roughly means 'the misfortune of honor,' the misfortune associated with the concept of honor as a social category (referring to the tremendous power of others' opinions about the individual). The phrase 'por la negra honrilla' (in English, for the sake 'of the damned appearance,' honrilla means 'false sense of honor') is proverbial (cf. the entry on "Honrilla” in Diccionario de Autoridades: “[. . .] Dimin. de Honra. Tomase freqüentemente esta voz por el puntillo o vergüenza con que se dexa de hacer alguna cosa porque no parezca mal: y las más veces se suele decir, Por la negra honrilla. Latín. Proprius honor, vel privata dignitas. LOP. Peregr. f. 130. Esta negra honrilla, este que dirán, suele muchas veces detener más que las christianas consideraciones" [(cf. note 604), vol. 4 (1734), p. 174b]; cf. as well: "HONRILLA, la vana presuncion de algunos necios q[ue] ponen la honra en impertine[n]cias, y ellos son los que andan inquiriendo, si el otro le toco en la honra, o no, por no nada" [Covarrubias, Tesoro (cf. note 779), Primera Parte, fol. 477r]). 
The following 'living image' that the interpretes describe is neither about animals nor humans, but about water. Chanfalla now declares it to be raining, and that the water pouring in streams from the sky came directly from the Jordan River. (From a Christian perspective, water from the Jordan River, which was regarded as the site where the baptism of Jesus by John the Baptist took place, is, so to speak, the 'prototype' of baptismal water.) Chanfalla then, furthermore, relates magical properties to this already special water, saying that according to legend, a bath in the Jordan River had rejuvenating power ${ }^{821}$ and that if touched by this water a woman's face would look like polished silver, and a man's beard would appear golden.

Chanfalla: Esta agua, que con tanta priesa se deja descolgar de las nubes, es de la fuente que da origen y principio al río Jordán. Toda mujer a quien tocare en el rostro, se le volverá como de plata bruñida, y a los hombres se les volverán las barbas como de oro. ${ }^{822}$

(pp. 229 f.)

821 Cf. "JORDAN. s. m. Qualquier cosa que remoza, o rejuvenece. Es tomada la metáphora de que se decía que los que se bañaban en el rio Jordán rejuvenecían” (RAE, Diccionario de Autoridades [cf. note 604], vol. 4 [1734], p. 320b).

822 This continues the biblical allusions that Chanfalla integrates into the ironic play: first Samson, then the mice descendants of those from Noah's Ark, and now the Jordan River. This allusion also illustrates the problem with the strict separation between the Jewish and Christian faiths. The Jordan River is central to both the Jewish tradition (cf. Jos $3 \mathrm{ff}$. [crossing the Jordan and 'entering the Promised Land']) and the Christian one, namely where Jesus is said to have been baptized by John the Baptist; an event of relevance in the history of salvation (cf. Mt 3,13-17, here 3,16 f.: "Baptizatus autem Jesus, confestim ascendit de aqua, et ecce aperti sunt ei cæli: et vidit Spiritum Dei descendentem sicut columbam, et venientem super se. Et ecce vox de cælis dicens: Hic est Filius meus dilectus, in quo mihi complacui”/“And Jesus, when he was baptized, went up straightway out of the water: and, lo, the heavens were opened unto him, and he saw the Spirit of God descending like a dove, and lighting upon him: And lo a voice from heaven, saying, This is my beloved Son, in whom I am well pleased'). (It should be noted that John the Baptist is a constitutive part of the last scene evoked in the show, the 'Dance of Herodias' or Salome; this is already indicated by the mention of the Jordan River, where he was active. Thus, water from the Jordan River represents the baptismal water par excellence. The ritual of baptism marks purification (of sins) and is above all the sacrament by which one 'becomes Christian.' In the context of the discourses to which the entremés refers, it is therefore of crucial importance. According to the limpieza de sangre laws, baptism is not sufficient. One cannot be 'purified' from 'impure' descent, one cannot become a 'true' Christian through baptism; thus, the cristianos nuevos are under the constant suspicion that they are only Christians 'in appearance' (baptized). The comedy of the scene then unfolds around the further attribute of the water that Chanfalla tells them, namely the change in appearance, with the women striving to get wet with the (fake) water in order to 'beautify' and 'rejuvenate' themselves, while the men insist on avoiding it. We can only speculate on the underlying meaning of the gender-specific desire for ('plata bruñida en el rostro') or avoidance of 
Again the spectators react immediately, taking up the fiction, expanding on it, and turning it into 'their' (also concretely sensually perceived) own truth. To a certain extent, they themselves become improvising figures of the play. Castrada instructs her cousin to uncover her face in view of the beautifying potential of the water, while asking her father to protect himself in order not to get wet. She herself opens her mouth wide and turns her face 'to the sky' or 'to the ceiling', respectively, and 'drinks,' pronouncing the water to be delicious. While Castrado is assuring his daughter that the men would all cover up, Benito makes the fairly vulgar, but funny, comment that the water had already run down his back to the "canal maestro." Capacho, on the other hand, emphasizes his 'integrity,' stating that he was as dry as esparto grass.

CASTRADA: ¿Oyes, amiga? Descubre el rostro, pues ves lo que te importa. ¡Oh, qué licor tan sabroso! Cúbrase, padre, no se moje.

JuAn: Todos nos cubrimos, hija.

BENITO: Por las espaldas me ha calado el agua hasta la canal maestra.

CAPACHO: Yo estoy más seco que un esparto.

The Gobernador again speaks in an aside, and is once again the only one who perplexedly questions the spectacle, or more precisely, who has doubts about his own perception, which does not match what the others claim to see and feel. In view of the rules of the retablo, this is causing him to question his own lineage. The Gobernador's uncertainty has grown with each aparte. While in the first instance he realizes that, unlike the others, he did not 'see' anything, he still considered himself legitimately born and a proper Christian. After the 'second appearance' he alluded to the negra honrilla and decided that he would, for the sake of appearances, also say that he was seeing something. At this point however, he begins to be concerned, 'recognizing' that he might be illegitimate, and asking: 'But what if I was to be the bastard among all those lawful?' (“GoBERNADOR: [Aparte.] ¿Qué diablos puede ser esto, que aún no me ha tocado una gota donde todos se ahogan? ¿Mas si viniera yo a ser bastardo entre tantos legítimos?" p. 230). It is however only the readers/spectators who know of the Gobernador's confusion; his peers - presumably because they themselves are preoccupied with 'proving' that they 'see everything'

('barba de oro') contact with the water; perhaps it references a (possibly sexual or vulgar) subtext the meaning of which is now, 400 years later, lost to us. 
Chanfalla describes - do not notice that he sees nothing, even if he has not yet openly remarked on the show as they have done. When the Gobernador observes the discrepancy between his own perception and the behavior of the rest, he in effect becomes a spectator of his fellow spectators or rather of their 'acting.'

Benito Repollo then begins to thunder against Rabelín and his musical accompaniment, as he had before the performance: "BENITO: Quítenme de allí aquel músico; si no, voto a Dios que me vaya sin ver más figura. ¡Válgate el diablo por músico aduendado, y qué hace de menudear sin cítola y sin son!” (p. 230; if one did not take the musician out of his sight, he would leave the place of performance without even looking at another image. This goblin of a musician should be taken by the devil) and complains about the unbearably dissonant music that Rabelín is making, repeating himself over and over again without any sense of rhythm or sound ('y qué hace de menudear sin cítola y ni son'). It should be noted that - at least based on the stage direction - it is not clear whether Rabelin is actually 'playing music' at all. Benito is the only one from the audience who refers to the 'musician' and his 'playing.' The description 'menudear sin cítola ni son' is ambiguous and could also mean only that he repeated the supposed movement of playing, without actually having an instrument, a cithara, or making any sound at all. Given that Chanfalla and Chirinos make no mention of the 'action' of the musician Rabelin (or rather the description of his music), the spectator-actor Benito can freely improvise in this respect, once again evading any potential suspicion that he was among those not able to see the show. Rabelín responds angrily that the alcalde should stop complaining about his music because he was playing the way he was taught to please God. Benito reacts with even more anger, insulting him and threatening him with violence and demanding that he disappear behind the curtain, or he would throw a bench at him. Rabelín responds that it must have been the devil who brought him to this village. ${ }^{823}$ Capacho draws attention back to the 'stage' or rather to the image narrated by Chanfalla that transgressed the boundary between stage and audience. He declares that the water from the Jordan River was fresh, because although he had covered himself as well as he could, some water had nevertheless dripped onto his moustache, which now, he wagers, was as yellow as a piece of gold.

823 "RABELÍn: Señor alcalde, no tome conmigo la hincha, que yo toco como Dios ha sido servido de enseñarme. BENITO: ¿Dios te había de enseñar, sabandija? ¡Métete tras la manta; si no, por Dios que te arroje este banco! RABELín: El diablo creo que me ha traído a este pueblo" (p. 230). 
Benito immediately joins in, uttering that it was fifty times worse. The transformation of fiction into reality is intensified yet again, as the rest of the audience takes up the evoked image and expands upon it independently. (“CAPACHO: ¡Fresca es el agua del santo río Jordán! Y aunque me cubrí lo que pude, todavía me alcanzó un poco en los bigotes, y apostaré que los tengo rubios como un oro. BENITO: Y aun peor cincuenta veces” pp. 230 f.).

Chirinos quickly begins to explain the next 'performance' saying that at least two dozen rampant lions ("leones ra[m]pantes") and honey-eating bears ("osos colmeneros") would now be arriving, while at the same time, she, remarkably, qualifies the animals as fantastic or imagined, saying that all living things should beware of them, for even though they are "fantásticos" they are still able to cause harm, with drawn swords ("espadas desenvainadas") that rival the strength of Hercules. ("CHIRINOS: Allá van hasta dos docenas de leones ra[m]pantes ${ }^{824}$ y de osos colmeneros. Todo viviente se guarde, que, aunque fantásticos, no dejarán de dar alguna pesadumbre, y aun de hacer las fuerzas de Hércules, con espadas desenvainadas” p. 231). It should be noted that all these images: the 'rearing, rampant lions' (leones rampantes), bears (osos [colmeneros]), swords (espadas), and Hercules are references to heraldry and the Spanish Royal coat of arms (which features the Pillars of Hercules and the lion). ${ }^{825}$ In view of this horde of dangerous animals about to bear down on them, Castrado and Benito turn to Chanfalla in outrage. Was he now intending to fill their house, i.e. his, with lions and bears, says the former ("JUAN: Ea, señor Autor, ¡cuerpo de nosla! ¿Y agora nos quiere llenar la casa de osos y de leones?” p. 231). The mayor becomes even more indignant, demanding that 'more peaceful figures' appear or he would put a stop to the show immediately, and referring to Tontonelo, the retable's presumed inventor, says: "BENITO: ¡Mirad qué ruiseñores y calandrias nos envía Tontonelo, sino leones y dragones! Señor Autor, [o] salgan figuras más apacibles, o aquí nos contentamos con las vistas, y Dios le guíe, y no pare más en el pueblo un momento" (p. 231; Tontonelo would not send any nightingales and woodlarks, only lions and dragons. Either more peaceful characters must appear or they will be content with those already seen, and may God guide the actors, but they should not stay in their village a single moment longer). Juana Castrada, however, asks

824 Cf. the passage in the first edition, fol. 246v ("Che. Allà va[n] hasta dos dozenas de leones ra $[\mathrm{m}]$ pantes, y de ossos colmeneros, todo viuie[n]te se guarde, que aunque fantasticos, no dexaran de dar alguna pesadu[m]bre, y aun de hazer las fuerças de Hercules con espadas desembaynadas.”).

825 A rampant bear eating from a strawberry tree features in the coat of arms of Madrid. 
Benito to allow the bears and lions to appear, even if it was only for them (Castrada and Teresa), because they would enjoy it. Castrado interjects in amazement that his daughter had been so scared of the mice before, and now she wished to see bears and lions? To which his daughter replies that everything that is new is pleasing. ("CASTRADA: Señor Benito Repollo, deje salir ese oso y leones, siquiera por nosotras, y recebiremos mucho contento. JuAN: Pues, hija, ¿de antes te espantabas de los ratones, y agora pides osos y leones? CASTRADA: Todo lo nuevo aplace, señor padre” p. 231). In other words, the spectators are once again discussing the 'content' of the show and what they consider to be appropriate or inappropriate within its framework. Although they do not question 'the fact' that something is being seen (with the exception of the Gobernador, however, in the form of asides), the images described by Chanfalla and Chirinos are not at all easily accepted, but criticized as too dangerous and too exciting, and they ultimately even make requests regarding the upcoming parts of the 'performance.' Furthermore, the punch line of this scene, which is simultaneously comic and serious, is that the ideology-driven delusion of the audience of the show has reached such a level that the explicitly-mentioned fantastic/imaginary aspect of the beasts described by Chanfalla and Chirinos are not even taken into account and it is assumed, as in the 'mice scene,' that they are real animals that would soon be seen on the stage.

Chirinos now 'conjures up' the last image of the show: "Esa doncella, que agora se muestra tan galana y tan compuesta, es la llamada Herodías, cuyo baile alcanzó en premio la cabeza del Precursor de la vida. Si hay quien la ayude a bailar, verán maravillas” (pp. 231 f.; 'This girl, who appears so elegantly dressed before you, is Herodias, whose dance received as a prize the head of the harbinger of life. If somebody helps her dance, there will be seen some wonders'). There is now an explicit demand for interaction between stage and audience, for the spectators to be transformed into characters in the fictitious stage show.

As was the case with the first 'scene' with the blind Samson, this is also an event mentioned in the Bible, this time from the New Testament, albeit in a slightly distorted form. According to the Gospels, the daughter of Herodias (traditionally known as Salome, although this name is not specified in the biblical narrative) danced for her stepfather Herod Antipas in honor of his birthday. As a reward for her performance, he promised to fulfill her every wish. At her mother Herodias' instigation (“for Herodias' sake," as it says in Mark's Gospel), she asked that the head of John the Baptist, already imprisoned by Herod, be brought to her immediately on a platter. According to Christian teaching, John the Baptist is considered the precursor of Jesus Christ, who in turn is considered 'the life' (hence the phrase here: 'Precursor 
de la vida'). Herodias was furious with John the Baptist for his criticism of her marriage to Herod after she had previously been married to Herod's brother, Philip. ${ }^{826}$

The 'dancing scene' that ensues is quite licentious; Benito in particular appears to be totally carried away, enthusiastically praising, in a vulgar tone, the 'beautiful girl's' sensual dance and inviting his nephew, ${ }^{827}$ who was skilled in the use of castanets, to dance with her, to which the latter immediately agrees:

BENITO: ¡Ésta sí, cuerpo del mundo!, que es figura hermosa, apacible y reluciente. ¡Hideputa, y cómo que se vuelve la mochac[h]a! - Sobrino Repollo, tú que sabes de achaque de castañetas, ayúdala, y será la fiesta de cuatro capas.

SoBRINo: Que me place, tío Benito Repollo.

Then a saraband is played, that is, there is 'actually' the sound of dance music, audible also to the external audience of El retablo de las maravillas, as the stage direction says: “(Tocan la zarabanda.)” (p. 232). The inner spectator Capacho immediately specifies the kind of dance taking place with the imaginary Herodías and the 'real' Sobrino, saying: “†Toma mi abuelo, si es antiguo el baile de la zarabanda y de la chacona!” (p. 232). Zarabanda ('saraband') and Chacona ('chaconne') were folk dances with fast tempos and 'lascivious moves' that were considered immoral during this period. Benito eggs on his dancing nephew, yelling: "Ea, sobrino, ténselas tiesas a esa bellaca jodía.” But he then asks, in bewilderment, that if she (the figure of the dancing Herodias/Salome, whom he had just despisingly called bellaca jodía) was Jewish, how was it then possible that she could also see all the marvels: "Pero, si ésta es jodía, ¿cómo vee estas maravillas?” (p. 232). Chanfalla's ironic answer to this is simply: “Todas las reglas tienen excepción, señor Alcalde” (p. 233; 'There are no rules without exceptions'). The boundaries between the play/imagination/reality levels now seem to have been completely dissolved and the play reaches a new

826 Cf. $M t$ 14,3-12 and $M k$ 6,17-29, quote: $M k$ 6,17. It is Flavius Josephus (37/38-100 CE) who gives Herodias' daughter the name Salome (cf. Antiquitates Iudaicae XVIII, 5,4); Josephus also lists a different motivation for the death of John the Baptist, writing that Herod Antipas captures him out of fear of rebellion, and then killed (on the death of John the Baptist, cf. Antiquitates Iudaicae XVIII, 5,2) (used edition: Flavius Josephus, Ioudaikē Archaiologia/Jewish Antiquities [Greek-English], ed. and trans. Henry St. John Thackeray, Ralph Marcus, Louis H. Feldman, and Allen Wikgren, in: Josephus, 9 vols., Cambridge, MA/London 1926-1965, vols. 4-9 [1930-1965]; cf. vol. 9 [1965]: Jewish Antquities, Books XVII-XX, pp. 92 f. and pp. 80 f.).

827 The figure of Benito Repollo's nephew was introduced in the stage direction describing the entry of the characters before the 'play within the play' as "UN SOBRINO de Benito, que ha de ser aquel gentilhombre que baila." (p. 226). 
height of absurdity. Benito, spectator of the Retablo de las Maravillas, not only 'sees' the 'living image' (the figure of the dancing Herodias) evoked by the autores, but positions this image as itself a spectator subject to the rules of spectatorship set down by Chanfalla.

At this point the 'outside' (the play not within the play) interferes with the 'inner play frame.' A trumpet sounds and a 'real person' enters the room. This ('real life') character is un furrier de compañias, a quartermaster (furrier) of the royal military seeking food and shelter for his troops. The stage direction says: "(Suena una trompeta, o corneta dentro del teatro, y entra UN FURRIER de compañias.)” (p. 233). The quartermaster asks for the Gobernador, and requests that accommodation be organized for thirty cavalry soldiers who were arriving within half an hour, if not sooner, as the trumpet announcing them had already sounded. As fast as the quartermaster appeared, he as quickly disappears: "FURRIER: ¿Quién es aquí el señor Gobernador? GOBERNADOR: Yo soy. ¿Qué manda vuesa merced? FURRIER: Que luego al punto mande hacer alojamiento para treinta hombres de armas que llegarán aquí dentro de media hora, y aun antes, que ya suena la trompeta; y adiós. [Vase.]” (p. 233).

Benito then instantly declares that he bets that it was "el sabio Tontonelo," that is, the 'creator' of the Retablo de las Maravillas, who was sending them the soldiers ("BENITO: Yo apostaré que los envía el sabio Tontonelo” p. 233). Benito does not perceive the 'real' appearance of the quartermaster and instead integrates him and his words into the 'play' (the soldiers announced by the furrier had been 'sent' by Tontonelo and were thus part of the retablo). But Chanfalla denies Benito's assumption, saying that there was indeed a cavalry company that had been quartered two miles away ("CHANFALLA: No hay tal; que ésta es una compañía de caballos que estaba alojada dos leguas de aquî” p. 233). The mayor is outraged:

BENITO: Ahora yo conozco bien a Tontonelo, y sé que vos y él sois unos grandísimos bellacos, no perdonando al músico; y mirá que os mando que mandéis a Tontonelo no tenga atrevimiento de enviar estos hombres de armas, que le haré dar docientos azotes en las espaldas, que se vean unos a otros.

(pp. 233 f.)

He insists that the soldiers, to whom the villagers would have to provide quarters, were in fact sent by Tontonelo. When he states that he now knows that they all - Tontonelo, Chanfalla, Chirinos, Rabelín - are the greatest scoundrels, this supposed 'knowing' does not refer to the actual deception being perpetrated on him by Chanfalla and Chirinos, but rather refers to the play having 'brought' the soldiers to the village, and the inconvenience this will now cause. The integration of reality into fiction (which Benito does not perceive), the dissolution of the boundary between play and seriousness, is so distorted that 
Benito threatens Chanfalla and commands him to tell Tontonelo not to dare send them these men in arms, otherwise he will hit him 200 times on the back. Even when Chanfalla again objects that the soldiers were not sent by Tontonelo, Benito continues to insist that they were, as were all the other 'nastinesses' and 'pests' ("sabandijas") that had been sent to them and that he had seen himself: “ChANFAlla: ¡Digo, señor alcalde, que no los envía Tontonelo! BENITO: Digo que los envía Tontonelo, como ha enviado las otras sabandijas que yo he visto” (p. 234). ${ }^{828}$ Upon this 'cue' ('que yo he visto'), which refers to the rules of the show, Capacho immediately jumps in and stresses that they all had seen it (“САРACHO: Todos las habemos visto, señor Benito Repollo" p. 234). Benito is then at pains to reassure him that he had not claimed the opposite, and again, full of impatience and anger, rudely addresses Rabelín, telling him to stop playing, or he would smash in his skull ("BENITO: No digo yo que no, señor Pedro Capacho. - ¡No toques más, músico de entre sueños, que te romperé la cabeza!” p. 234). Directly thereafter the quartermaster returns and inquires whether the quarters were ready, as the horses were already in the village. Benito becomes infuriated, since he had strongly requested that Chanfalla make sure (i.e. instruct Tontonelo) that the soldiers were not to come. He is convinced that Tontonelo is responsible for the soldiers' arrival and angrily threatens to beat Chanfalla. In the face of this danger, Chanfalla turns to everyone, saying that they were witnesses of the mayor threatening him. Chirinos also tries to draw the attention of those present, especially the quartermaster, to the danger posed by Benito, saying that she would summon them as witnesses of the mayor's claim that what His Majesty had ordered (i.e. the obligation of the population to support his army, to provide quarters for the royal soldiers) was a command of the sage Tontonelo. Thereupon the angry Benito threatens her again. $^{829}$

It should be pointed out that the aspect of the soldiers' reality status brings into play a (quite seriously intended) critical reference to the undecidability of

828 This also means that Benito classifies the king's soldiers as 'sabandija' ('vermin,' 'worms,' 'bugs').

829 "FuRRIER: Ea, ¿está ya hecho el alojamiento? Que ya están los caballos en el pueblo. BENITO: ¿Qué, todavía ha salido con la suya Tontonelo? ¡Pues yo os voto a tal, Autor de humos y de embelecos, que me lo habéis de pagar! Chanfalla: Séanme testigos que me amenaza el Alcalde. ChIRINos: Séanme testigos que dice el Alcalde que, lo que manda S[u] M[ajestad], lo manda el sabio Tontonelo. BENITO: ¡Atontoneleada te vean mis ojos, plega a Dios Todopoderoso!” (p. 234). 
truth and illusion as postulated by skepticism. The serene skeptical assumption of isosthenia is far from being compatible with all (real-life) situations, because according to the prevailing legal usus of the time, a village that refused to fulfill the obligation of supplying troops could be plundered and burned. Thus, an answer to the question of whether the soldiers are 'real' or (only) part of the stage spectacle ultimately cannot be avoided; and depending on the compatibility or incompatibility of the subjective perception of 'true realities,' the incorrect decision, or non-decisive 'suspension of judgment,' could cost one one's life.

The Gobernador now interjects that in his opinion the soldiers were real and not part of a play or a joke ("GOBERNADOR: Yo para mí tengo que verdaderamente estos hombres de armas no deben de ser de burlas” p. 234). The Gobernador was the only member of the audience who doubted the 'authenticity' of the performance, but this was only, and this is relevant, related to his own perception, which differed from what the other spectators claimed to have seen. He had admitted, though only to himself, that he was not seeing anything at all, and this caused him to doubt, not the show, but his own origins, which he had hitherto considered impeccable, and led him to choose instead to pretend to see rather than admit that he could not. Despite his own experience, and his close observation of his fellow audience members and their reactions during the play, it never occurred to him to suspect that they too might only be pretending to see the show. His astonishment always related to the discrepancy he noticed between his own perception and that of everyone else. Now, although he appears to be siding with Chanfalla and Chirinos, he does not do so by referring objectively to his own assessment of the situation, that the soldiers' arrival was precisely not part of a burla, i.e. that it and they were real. The quartermaster is stunned by the Gobernador's remark and doubts his sanity for considering the possibility that the soldiers could have been a joke, and wonders whether he was sound of mind ("FuRRIER: ¿De burlas habían de ser, señor Gobernador? ¿Está en su seso?” p. 234). Castrado, however, in turn, continues the argument that they could well also have come from Tontonelo, i.e. be part of the play. The ontological status of the scenes that 'appeared' in the show are described here by means of an adjectivization of the name of its (supposed) inventor Tontonelo (and their real existence, in view of the meaning of that name is taken ad absurdum): they could have been atontoneleados - 'caused by Tontonelo' - like all the other things that they had been watching. He then asks Chanfalla to let the young Herodias perform again, so that the quartermaster could see something he had never seen before. Perhaps this would also make him leave quickly: "JuAN: Bien pudieran ser atontoneleados; como esas cosas habemos visto aquí. Por vida del Autor, que haga salir otra vez a la doncella Herodías, porque vea este señor lo que nunca ha visto; quizá con esto le 
cohecharemos para que se vaya presto del lugar" (p. 234). Chanfalla immediately re-invokes the image of the dancing Herodias and the "play within the play' continues. So be it, says Chanfalla, and then describes how Herodías was already giving her former dancing partner a sign that he should again help her in her dancing ("CHANFALLA: Eso en buen hora, y veisla aquí a do vuelve, y hace de señas a su bailador a que de nuevo la ayude” p. 235). Instantly, Benito's sobrino is willing to resume his 'part,' assuring the spectators that it would certainly not be because of him that the dance would not continue. Benito is immediately on fire again, cheering on his nephew (it can be assumed that el Sobrino actually does dance): "SoBRINO: Por mí no quedará, por cierto. BENITO: ¡Eso sí, sobrino, cánsala, cánsala; vueltas y más vueltas; ¡vive Dios, que es un azogue la muchacha! ¡Al hoyo, al hoyo! ¡A ello, a ello!” (p. 235). The quartermaster, witnessing the spectacle of the wildly dancing young man and his uncle's boisterous encouragement, and in light of the previous discussion, gives vent to his deep astonishment, expresses his incredulity as to what is taking place before his eyes and ears and assumes that those present were crazy. He asks amazedly which doncella and which dance they were talking about, and who this Tontonelo was. At this, Capacho asks if he was not seeing "la doncella herodiana," whereupon the confused quartermaster reacts angrily, demanding again exactly what doncella was he supposed to be able to see. ("FURRIER: ¿Está loca esta gente? ¿Qué diablos de doncella es ésta, y qué baile, y qué Tontonelo? CAPACHO: ¿Luego no vee la doncella herodiana el señor furrier? FURRIER: ¿Qué diablos de doncella tengo de ver? p. 235) After saying that even with the best will in the world he was not seeing any such figure, the villagers immediately draw the only conclusion relevant to them: the quartermaster was unable to see anything because he lacked the 'pure ancestry' that was the precondition for seeing the show. They therefore now belittle him ${ }^{830}$ as 'belonging to the others,' crying that he was 'one of them' (i.e. not cristiano viejo), ${ }^{831}$ and call out:

CAPACHO: Basta: de ex il[l]is es.

GOBERNADOR: De ex il[l]is es; de ex il[l]is es

JuAN: Dellos es, dellos el señor Furrier; dellos es.

830 That is what it must be called here, in the context of a community based on racist principles, which mercilessly excludes 'others' who are, according to these principles, supposedly 'inferior.'

831 The other (anchored in the comic) sign of 'dishonor' or the reason for not being able to see anything, i.e. the aspect of 'illegitimate birth,' is now no longer relevant. 
FURRIER: ¡Soy de la mala puta que los parió; y, por Dios vivo, que, si echo mano a la espada, que los haga salir por las ventanas, que no por la puerta!

CAPACHO: Basta: de ex il[l]is es.

BENITO: Basta: dellos es, pues no vee nada.

FURRIER: ¡Canalla barretina!: si otra vez me dicen que soy dellos, no les dejaré hueso sano.

BENITO: Nunca los confesos ni bastardos fueron valientes; y por eso no podemos dejar de decir: dellos es, dellos es.

(p. 235)

The escribano Capacho is the first to shout out that the furrier was 'one of them (the others),' using the Latin expression ex illis, which refers to a passage in the New Testament referred to as "the Denial of Peter." During the Last Supper Jesus foretold that he would be arrested that night and that Peter would deny knowing him three times before morning (before the cock crows). After Jesus was arrested, Peter followed behind and stopped by a fire outside the house where Jesus was imprisoned. A servant girl recognized him as 'one of them' ("ex illis"), i.e. one of the disciples of Jesus, which Peter then denies. ${ }^{832}$ The Latin words used to accuse Peter of being a disciple of Jesus (i.e. a Christian) are now used by the villagers to identify the quartermaster as a non-Christian. The Gobernador, too, immediately joins in the accusation and repeats the charge ('de ex illis es') twice, despite the fact that he himself could not see anything of what everyone claimed to see. It could have been possible, now that his own perception coincides with that of another person, for him to at least question the reliability of the show; there would be at least the possibility of problematization. But the Gobernador proceeds according to the strategy he has devised, namely when in doubt continue to assert that he, too, could see something, because of the all-important negra honrilla and, especially because of the now apparent danger of becoming, like the quartermaster, the target of

832 Cf. Mt 26,73 ("Et post pusillum accesserunt qui stabant, et dixerunt Petro: Vere et tu ex illis es: nam et loquela tua manifestum te facit”/“And after a while came unto him they that stood by, and said to Peter, Surely thou also art one of them; for thy speech bewrayeth thee' ['Peter Denies Jesus' altogether: $M t$ 26,69-75]); cf. $M k$ 14,69 f. ("Rursus autem cum vidisset illum ancilla, cœpit dicere circumstantibus: Quia hic ex illis est. At ille iterum negavit. Et post pusillum rursus qui astabant, dicebant Petro: Vere ex illis es: nam et Galilæus es”/‘And a maid saw him again, and began to say to them that stood by, This is one of them. And he denied it again. And a little after, they that stood by said again to Peter, Surely thou art one of them: for thou art a Galilaean, and thy speech agreeth thereto' [the passage as a whole: $M k$ 14,66-72]); cf. as well $L k$ 22,54-62, here $L k 22,58$. 
the others' rage. The quartermaster functions as a scapegoat, enabling the unleashing of rage against the 'intruder,' the 'outsider.' He was ex illis, a member of the despised and hated 'New Christians.' It is now that Castrado and Benito, seeing the retablo's rules and the order of their community confirmed, also join in the accusations that he was dellos because he could not see anything. The furrier, however, becomes angry and threatens them with violence. If they claimed even one more time that he was 'one of them' he would draw his sword and not leave a healthy bone in them. Benito then argues that neither confesos nor bastardos had ever been brave and they would therefore not cease to say that 'He is one of them.' The threat of real harm is ignored in favor of established convictions about 'these others.'

The 'play within the play' and the play as a whole end in bloody chaos. The quartermaster defends himself against the villagers, finally drawing his sword and stabbing several of them. Benito beats up the musician Rabelín (as he had repeatedly threatened to do). For their part, Chirinos and Chanfalla are pleased with the result of their scam. Chirinos takes down the blanket, saying that 'the devil had probably blown the trumpet and had made the soldiers come at the right time' (that is, before their fraud could be discovered). Thereupon Chanfalla says, and these are the last words of this Cervantine interlude, that the events had been extraordinary, the virtue of the retablo was intact with nothing to prevent them from presenting it to people the next day, and that they themselves should celebrate their triumph in this battle with the cry of viva Chirinos and Chanfalla!

\footnotetext{
FURRIER: ¡Cuerpo de Dios con los villanos! ¡Esperad!

[stage directions:] (Mete mano a la espada, y acuchíllase con todos; y el ALCALDE aporrea al RABELLEJo; $y$ la CHIRINos descuelga la manta y dice.)

CHIRINos: El diablo ha sido la trompeta y la venida de los hombres de armas; parece que los llamaron con campanilla.

Chanfalla: El suceso ha sido extraordinario; la virtud del Retablo se queda en su punto, y mañana lo podemos mostrar el pueblo; y nosotros mismos podemos cantar el triunfo desta batalla, diciendo: ¡Vivan Chirinos y Chanfalla!

(pp. 235 f.)
}

The ending of El retablo de las maravillas is unique among Cervantes' interludes for its chaos and excessive violence. It is the only entremés in the collection Ocho comedias y ocho entremeses nuevos, nunca representados that does not end with singing and (usually also) dance. At the time of Cervantes' writing the 'harmonious finale' had become an increasingly dominant feature of the genre as a whole, largely replacing the chaotic 'brawl ending' 
(final a palos) customary in the early interludes, such as Lope de Rueda's ( 1510-1565) pasos. Yet it is not that the dance and music, typical of entremés per se, are missing here. They are actually an integral part of what one could call a decisive characteristic of the interlude, namely, the intricate play of reality versus fiction/imagination/pretend and its related theme of perception. In the 'Dance of Herodías,' the last of the scenes evoked by the engañadoresautores Chirinos and Chanfalla, the audience members not only applaud the 'performance' but also become (actual) participants in the (imagined) stage play. Interrupted by the appearance of the furrier, when the dance is resumed again before him, a spectator who is not privy to the premise of the Retablo de las Maravillas, his statement that he does not see any dancing woman constitutes the beginning of the (violent) end of both the 'play within the play' and the play itself. The villagers, who have been 'watching' the retable of marvels under the terms of the rules given to them (and helping shape it, up to point of delusion), attack the quartermaster, who then stabs them with his sword. The partly imagined, partly real dance ends with the general excess of violence that concludes the play. Benito's nephew dances somewhat obscenely with the 'invisible' Herodías - he too, at least presumably, will be stabbed by the quartermaster. Also the musician Rabelin, who has been ridiculed from the very beginning of the play and whose 'playing' and appearance had been contemptuously remarked upon repeatedly during the 'play within the play' by Benito, is now - as he has been threatened several times by his tormentor beaten up. Thus, it is not music and dance, but their 'destruction' that brings an end to the entremés.

El retablo de las maravillas is a polyvalent dramatic text characterized by a complex layering of illusion and reality in which the problematization of distinguishing between seeming and being, fake and real, unfolds by means of the 'play within the play.' This 'inner play' is not a conventional theater within the theater. Designated a puppet theater, it is, in fact, a puppet theater without puppets, in a sense, an 'invisible' play within the play. The figures and events 'taking place' on stage are generated solely by the words of the play's 'directors' Chirinos and Chanfalla and by those of the spectators who take up the idea of these images and continue to expand on the narration. The 'play within the play' that is depicted has different levels of authorship. As Montiel, Chanfalla narrates the actions that take place within the Retablo de las Maravillas, which he pretends was created by 'el sabio Tontonelo' (as the spectators increasingly involve themselves with the fiction, they constantly refer to Tontonelo as the authority, or the one responsible for the 'content' of the play). In addition, on the one hand the play is also influenced by being part of the deception perpetrated by Chanfalla and Chirinos (only the readers/ 
spectators know of this dimension), and, on the other hand, it is also marked by the idea of the miraculous and wondrous (and is presented as such to the inner audience). The performance is here linked to the seeing of its perceivers, limited to those of limpieza de sangre and legitimate birth. The suspension of disbelief on the part of the audience, generated mainly by their fear of being regarded as 'impure' (in the sense of the religiously-based racist discourse) and consequently exposed to social exclusion, leads them to do everything to avoid the slightest doubt of their seeing the events being performed in the retable. Cervantes has addressed the obsession of limpieza de sangre (and the all-pervasive honra, the external appearance that determines social life) by means of a bogus theater performance. The delineation between stage and reality (internal action and framework plot) are fluid from the very beginning, with a constant crossing of the boundaries between play and seriousness, including the ironic and comic subtexts. The spectators themselves become 'actors,' embracing (all the absurd) images and expanding upon them, turning fiction into reality. The 'events on the stage,' as well as the audience and their reactions become objects of observation. The discrepancy between one's own perception and that of others, and the related question of how one obtains a reliable understanding of the world based on this perception - is made evident by the Gobernador's apartes and culminates with the appearance of the quartermaster. It is not only about the individual's perception of the external world, but about a reciprocal interplay; not only about the problems of perception as such, but also about the risks and behavioral strategies resulting from a situation of mutual observation. The audience accepts the rules of the performance because these rules also determine social life in general. The play draws attention to the manipulative force of ideology on subjective perception. We have already discussed how this was manifest in the Gobernador and shall now look more closely at how this played out with another character, the scribe Capacho. After 'viewing' the first part of the play (Samson), Capacho's reaction is not (yet) clearly affirmative like that of Benito, but consists in a question. He tentatively asks Castrado: ‘¿Veisle vos, Castrado?’ [Can you see him?], to which the latter immediately affirms '¿Pues no le había de ver? ¿Tengo yo los ojos en el colodrillo?' [Why should I not see him?]. Capacho here can either be trying to ascertain whether or not Castrado's perception corresponds to his, i.e., that Castrado cannot see anything either, or it can also be read as trying to insinuate that perhaps Castrado cannot see it (referencing the constraints that determine who can see and who cannot), it is to this supposed doubt regarding his purity that Castrado responds to so vehemently. One may also call this a structure of isosthenia. In the second and third retablo-scene evoked by Chanfalla and Chirinos (the bull and the mice) 
Capacho's reactions are not mentioned. It is only in the fourth scene, with the water from the Jordan River, that we hear from him again. When Benito says that the wondrous rainwater has dripped down on to his canal maestra Capacho notes that he is completely dry: 'Yo estoy más seco que un esparto.' On the one hand, this could be understood as meaning that he is going along with the rules of the retablo and has protected his face, and particularly his beard, so well, for example with a hat, jacket or hands, that the water has not reached him. On the other hand, it could also indicate his actual 'not-seeing': he is dry because he does not perceive anything of the supposed rain water at all. Shortly afterwards, however, following the dispute between Benito and Rabelin, he too becomes an 'active player,' describing the water that has now also dripped on him as being fresh, saying that although he was covering himself as well as he could, a little bit had dripped on his moustache. He then takes things even further by saying that he bets that his beard is now as yellow as a gold coin. This in turn eggs on his fellow spectator/player Benito, who says that it was even fifty times worse. It is Capacho who, when the sobrino begins to dance with (the imaginary) Herodias, with music coming from offstage ('Tocan la zarabanda'), refers to the dance in concrete terms. Later, after the first appearance of the quartermaster, Benito says angrily to Chanfalla that the soldiers were part of the play like all the 'pests' he himself had seen, Capacho is at pains to stress that they all had seen them. It is Capacho who pushes the quartermaster as to whether or not he could see the doncella herodiana, and it is Capacho who is the first to denounce the quartermaster with the words 'ide ex illis es!', and expose him to the rage of the crowd. The Gobernador, who, apart from his asides stating that he actually does not see anything, has not made any comment throughout the entire 'performance,' but is now the very next character to join Capacho in crying 'de ex illis es!'

Against the background of what has already been discussed, it is worth taking a closer look at the play's title. Retablo means puppet theater, or, more precisely, the stage of the puppet show on which the puppets appear. This was a popular form of entertainment in Spain of the 16th and 17th centuries. The retablos (or teatro de titeres) were often performed in the rural areas by wandering performers, who tended to be of Italian origin. ${ }^{833}$ Apart from the play currently being discussed, Cervantes also used this form of theatrical performance in connection with the issues of perception, 'representation and interpretation,'

833 Cf. Kenworthy, The Entremeses of Cervantes (cf. note 779), p. 91; cf. to this altogether: John Earl Varey, Historia de los títeres en España (desde sus orígenes hasta mediados del siglo XVIII), Madrid 1957. 
and the instability of the boundaries between fiction and reality in the second part of the Quijote, where the motif of the puppet theater appears in the famous episode of the titerero Maese Pedro. ${ }^{834}$ The term retablo originally referred to

834 Cf. Miguel de Cervantes, Don Quijote de la Mancha, ed. John Jay Allen, 2 vols., 1st ed., Madrid 1977, vol. 2 (22nd ed. 2001): Segunda Parte del Ingenioso Caballero Don Quijote de la Mancha, chaps. 25-27, pp. 215-240, here pp. 218-235. The passage in brief: One evening Don Quijote and Sancho Panza meet the puppeteer Maese Pedro in an inn, who, as the innkeeper tells them, travels through the country with a 'fortune-telling' monkey and a retablo. The performance of the puppet show is preceded by a (likewise to be paid) 'questioning' of the monkey; however, as its owner explains, the monkey could not make any statements about the future, but only give information about the past and the present. When Sancho then asks the monkey how his wife was doing, Maese Pedro slaps himself on the shoulder, the monkey jumps up and moves his mouth for a while, as if whispering something in his ear. To the amazement of all those present, Pedro then identifies Quijote and Sancho as "[el] alabado caballero Don Quijote de la Mancha” (p. 221) and his squire; Teresa Panza, he continues, she is well, she is at work and sweetening it with some wine. They also ask the monkey whether what Don Quijote 'experienced' in the Cave of Montesinos (cf. chap. 23, pp. 197-207) was a dream or reality and content themselves with the 'answer' (articulated by Pedro according to the same procedure as before) that it is partly wrong and partly probable and that the monkey cannot say more at the moment. (In view of what has been discussed in this study, attention should be drawn here to the reference to the skeptical dream trope.) The puppet theater play that Maese Pedro then performs before all the guests and staff of the tavern (he himself operates the characters while his young servant acts as the interprete commenting on what is happening on stage) is about Don Gaiferos' liberation of his wife Lady Melisendra (introduced as the daughter of Charlemagne), who the Moors have held captive in Zaragoza. At first, Don Quijote knows how to distinguish between reality and fiction. For example, when the bells ring out and it is said that this sound was coming from the towers of the city's mosques, he indignantly interjects that the ringing of the bells is a great mistake, for Moors do not use bells. However, when the plot reaches the point where Melisendra and Gaiferos are on the run and persecuted by the Moorish King Marsilio and his soldiers, Don Quijote, with the intention of protecting the fleeing couple, draws his sword and begins to beat the puppets and the puppet theater, in order to present himself afterwards as the savior of the lovers and a true representative of chivalry. Later, he wants to compensate Maese Pedro for his destroyed puppet theater and shattered puppets, which he claims was consequence of a spell: the wizards chasing him were constantly transforming everything before his eyes, the figures and the events were real in his perception, this was the reason why he got angry and, according to his profession as a traveling knight, wanted to help the fleeing couple and acted with good intentions. When determining payment, however, Don Quijote again seems to believe in the fiction and when Maese Pedro identifies a torn puppet as Melisendra, he says that it could not be her, since the horse on which she had fled with Gaiferos had been so fast that the true Melisendra and her lover would certainly already be in France. Pedro thereupon simply says that the puppet was a servant of Melisendra and Quijote agrees to pay him for it and all the other shattered puppets and they have dinner together. At the beginning of the following (27th) chapter, the narrator discovers the true identity of Maese Pedro (with reference to the report of the Arab 
a group of wood paintings or carved wood panels (tablas) showing Christian scenes. The meaning of the word then became broader, and the term denoted the box of puppets used to depict scenes of Christian-religious content, before finally being used to denote a puppet theater in general. ${ }^{835}$ The genesis of the word, particularly with regards to the meaning of the term retablo as an altarpiece (or, also in English, 'retable,' or 'reredos,' respectively'), adds depth to the play, specifically its underlying religious theme. The combination of theater and religion is related to the religious theater of the time. This aspect is further emphasized, albeit not explicitly, with the use of the word maravillas (wonders/miracles). The status of miracles and the miraculous was one of the central points of dispute between Protestantism and Catholicism. Whereas Protestant theology negates the existence of miracles (beyond the historical ones in the Bible), Counter-Reformation Catholicism takes the position that miracles can happen again at any time (as determined by the ecclesiastical authorities). ${ }^{836}$ This debate over miracles, however, was also being taking place within the

historian Cide Hamete Benengeli): actually, he is Ginés de Pasamonte, a trickster known to the readers of the first part of the Quijote (cf. chap. 22 of the First Part, which deals with Don Quijote's 'Liberation of the Galley Prisoners': Cervantes, Don Quijote de la Mancha, ed. John Jay Allen, vol. 1 [20th ed. 2000]: El Ingenioso Hidalgo Don Quijote de la Mancha, chap. 22, pp. 270-281). After his escape from prison he had come to Aragón and was earning money as a puppeteer, an art that he mastered most besides playing the legerdemain. Sancho and Quijote do not recognize him because his face was half covered. He, on the other hand, recognized them immediately. He had bought the monkey from liberated Christians and taught him to act as if he were whispering in his ear and before coming to a place he made sure to inquire in the town nearby about all the goings on. The complexity of the Maese Pedro episode and its significance in terms of the illusion play and narrative structure of the novel can only be touched upon here. Cf. in this respect, for instance, already George Haley, "The Narrator in Don Quixote: Maese Pedro’s Puppet Show,” Modern Language Notes 80 (1965), pp. 145-165 (cf. p. 163: "Maese Pedro's puppet show is [...] an analogue to the novel as a whole, not merely because the burlesque legend that Maese Pedro recreates with puppets is a reductio ad absurdum of the same chivalric material that Cervantes burlesques through his characters, but also because it reproduces on a miniature scale the same basic relationships among storyteller, story and audience that are discernible in the novel's overall scheme. Yet analogy does not imply absolute identity, and the discrepancies in this case are as meaningful as the correspondence.”).

835 Cf. the entry in Covarrubias: "RETABLO, comunmente se toma porla tabla en que està pintada alguna historia de deuocion, y por estar en la tabla y madera, se dixo retablo. Algunos estrangeros suele[n] traer una caxa de titeres, que representa alguna historia sagrada, y de alli les dieron el nombre de retablos" (Covarrubias, Tesoro [cf. note 779], Segunda Parte, fol. 10v).

836 Regarding the Counter-Reformation position valid in Spain in the period of origin of the drama, cf. Concilium Tridentinum, Sessio XXV, 3-4 dec. 1563 "De invocatione, veneratione et reliquiis sanctorum, et de sacris imaginibus”/Session 25, 3-4 December 1563 'On invocation, 
Catholic Church. Erasmus, in particular, fiercely polemicized against the belief in miracles and the worshipping of relics. The Erasmian-skeptical ridicule of the belief in miracles, ${ }^{837}$ without being made explicit here, is conveyed in the play's title and its content, which express the idea that miracles are nothing but deception and illusion, perceived only as a result of ideological pressure.

The central miracle of Catholicism, i.e. the miracle of the Eucharist, was the subject of the auto sacramentales. This fact, together with the ambiguity of the title and use of the ideologeme of limpieza de sangre in the manipulation of perception (with its role as part of the 'attempt to (re-)constitute an Old Christian Spanish society'); as well as the Counter-Reformation dimension in the Spanish theater of the time, seem to indicate that in El retablo de las maravillas Cervantes was, at least with regard to the play's metatheatrical dimension, also casting an ironic and critical eye at the auto sacramental genre and its practice during this period. ${ }^{838}$

veneration and relics of saints, and on sacred images' (Canones et Decreta/Canons and Decrees [cf. note 374], pp. 774-776).

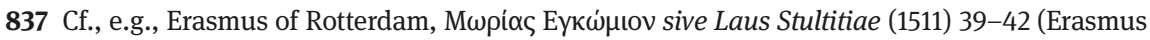
of Rotterdam, Praise of Folly/Moriae encomium, trans. and ed. Betty Radice, in: Collected Works of Erasmus [cf. note 67], vol. 27: Literary and Educational Writings, 5: Panegyricus; Moria; Julius exclusus; Institutio principis christiani, ed. Anthony H.T. Levi, Toronto/Buffalo/London 1986, pp. 77-154, pp. 112-116; Laus Stultitiae/Das Lob der Torheit, in: Erasmus of Rotterdam, Ausgewählte Schriften [Latin-German], ed. Werner Welzig, 8 vols., Darmstadt 1968-1980, vol. 2

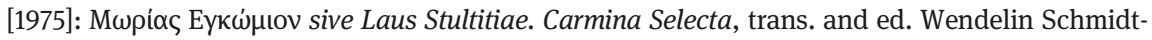
Dengler, pp. 1-211, here pp. 88-101); Erasmus, Enchiridion militis christiani (1503) 12-13 (Erasmus, The Handbook of the Christian Soldier/Enchiridion militis christiani, trans. and ed. Charles Fantazzi, in: Collected Works of Erasmus [cf. note 67], vol. 66: Spiritualia, ed. John W. O'Malley, Toronto/Buffalo/London 1986, pp. 1-127, here pp. 61-84; Erasmus, Enchiridion militis christiani/Handbüchlein eines christlichen Streiters, in: Erasmus, Ausgewählte Schriften [LatinGerman], vol. 1 [1968]: Epistola ad Paulum Volzium. Enchiridion militis christiani, trans. and ed. Werner Welzig, pp. 55-375, here pp. 168-241, esp. pp. 176-181).

838 In her analysis of Cervantes' Retablo, Bárbara Mujica focused on its connection to philosophical discourse, and emphasized the ancient dispute between dogmatists and skeptics, with dogmatism represented by the villagers, which is skeptically challenged by the retableplay of the fraudster couple, and displays the influence of Erasmian skepticism (Bárbara Mujica, “Cervantes' Use of Skepticism in El retablo de las maravillas,” in: Bárbara Mujica/ Sharon D. Voros/Matthew D. Stroud (eds.), Looking at the 'Comedia' in the Year of the Quincentennial: Proceedings of the 1992 Symposium on Golden Age Drama at the University of Texas, El Paso, March 18-21, Lanham, MD 1993, pp. 149-157). Cf. “[...] [T]he influence of Erasmus's humanistic skepticism on Cervantes has not been adequately explored. Cervantes's El retablo de las maravillas takes on a new clarity when examined within the context of the ancient debate between skeptics and dogmatists. Like Don Quijote, the councilmen of $E l$ 
Furthermore, the theme of honor, so central to Spanish culture of the time, is given satirical and ironic treatment that references not only the social discourse beyond the play, but can also be read with regard to the specific modeling of this theme in the comedia nueva. ${ }^{839}$ It has been noted that in his work, Cervantes seems to be in dialogue with the various literary genres of his time. In his prologue to his volume of plays, Cervantes referred to the omnipresence of Spanish drama as shaped by Lope de Vega and his school. In addition to the explicit allusions, often intended ironically, to the theater of the time ${ }^{840}$ in $E l$

retablo de las maravillas are dogmatists who espouse a world view based on unquestioned assumptions. [...] The goal of the tricksters is not to force the councilmen out of their dogmatic stance, but to play on the insecurity that dogmatism breeds" (p. 151); "Erasmus twists the skeptical argument regarding the unreliability of human perceptions into a satirical apology for man's need to dogmatize. Similarly, Cervantes creates characters whose very sense of self depends on their ability to twist reality to conform with their own system. Significantly, Cervantes does not judge his characters harshly for their tendency to dogmatize, even though he pokes fun at them" (p. 152). With regard to the classification of the burladores as 'skeptics' she writes: "I would not argue that Chanfalla and Chirinos are full-blown skeptics, but they are certainly pragmatists. Experience has taught them that appearances are deceiving; in fact, they are in the business of manipulating appearances. [...] Chanfalla and Chirinos are crooks, not philosophers; they achieve financial gain, not ataraxia. Nevertheless, within the context of the play, they are the winners" (p. 155); with regard to the conclusion, which tends in the result to that presented here, however, differs in the accentuation, see: "Although Cervantes was influenced by skepticism, through the gobernador he illustrates just how difficult it is to maintain a skeptical stance. Although Cervantes showed time and time again that human understanding is flawed, that the senses cannot be trusted, that the will transforms reality in accordance with preconceived notions and that social and personal circumstances influence an individual's judgement, he also knew that it was impossible for men and women living in society to suspend judgement about issues of vital importance to them. As a matter of fact, even Sextus taught that convention was a valuable guide to conduct. If dogmatism makes people intolerant, fanatical, and vulnerable to the machinations of manipulators such as Chanfalla and Chirinos, skepticism in its purest form does not offer a viable alternative” (p. 156 f.). Mujica's article is almost the only publication on El retablo de las maravillas that explicitly discusses Cervantes' dramatic text in the context of skepticism. A global study on the aspect of skepticism in Cervantes - with a focus on his main narrative work, Don Quijote - has been written by M. Ihrie (Skepticism in Cervantes [cf. note 2]).

839 In Lope de Vega's Arte nuevo de hacer comedias en este tiempo it says: "Los casos de la honra son mejores / porque mueven con fuerza a toda gente, / con ellos las acciones virtuosas, / que la virtud es dondequiera amada" (vv. 327-330; Lope de Vega, Arte nuevo de hacer comedias [cf. note 503]).

840 Chanfalla/Montiel claims that he was asked by the lay brothers running the corrales in Madrid to come remedy the financial distress caused by the lack of autores de comedias with his 'miracle retable'; the Gobernador presents himself as the author of 22 comedias, written one after the other, with which he wants to make the autores of the capital rich; Chirinos notes that there are so many writers of comedy, all of whom considered themselves famous, and so 
retablo de las maravillas, including the possible ironic reference to the auto sacramental genre mentioned above, the text also references the pattern of Lopean comedia. A sub-genre of the popular comedia de honor is the so-called 'peasant play/honor play' (comedia de la honra villana, comedia de labradores or comedia villanesca), exemplified by Lope de Vega's Fuenteovejuna (before 1614, publ. 1619) and Peribáñez y el Comendador de Ocaña (publ. 1614). In this context it is interesting to examine in more detail how Cervantes looks ironically at the connection between the code of honor and limpieza de sangre expressed in the comedia of the time. ${ }^{841}$ For example, the villager-protagonists of the honor plays all tend to be proud Old Christians ${ }^{842}$ and Cervantes seems to subvert the heroes of the comedia de honor by transforming them, in his work, into doltishly simple characters. The concept of honor so seriously reaffirmed in the comedia is, in Cervantes, renegotiated and ridiculed. While in comedias weddings tend to serve as a starting point for the conflict and are certainly a serious issue, ${ }^{843}$ in El retablo de las maravillas the wedding (hastily arranged in the Castrado house) is nothing but a sham, a fake occasion to serve as the excuse for the retablo performance. The comedias ideologically and politically reinforce the centralization of power, showing the honorable peasants submitting gladly to the absolute power of the kings and being recognized by their

many mediocre plays, which were always staged, so that mentioning them would not be worthwhile.

841 In this context, see Michael E. Gerli, "El retablo de las maravillas: Cervantes' 'Arte nuevo de deshacer comedias', "Hispanic Review 57 (1989), pp. 477-492.

842 "Yo soy un hombre, / aunque de villana casta, / limpio de sangre, y jamás / de hebrea o mora manchada" (vv. 3030-3033), emphasizes Peribáñez, who is sentenced to death when describing the events from his point of view in front of the royal couple (the murder of the Comendador to protect the honor of his wife Casilda, "también limpia, aunque villana, / virtüosa [...]” [vv. 3043 f.], from his sexual assault); after all, Peribáñez is not only acquitted and praised for his courage and his honor, but is appointed capitán, given the right to bear arms and financially rewarded. (Quoted after the edition: Lope de Vega, Peribáñez y el Comendador de Ocaña, ed. Juan María Marín Martínez, Madrid 1979).

843 In Fuenteovejuna, the village defends itself against a despotic Grand Commander after he kidnaps Laurencia during her wedding with Frondoso, rapes her and throws the groom into the dungeon; Peribáñez begins with the celebrations of the wedding between the protagonist and Casilda, which is interrupted by the arrival of the Comendador injured (by a bull!) who, from that moment on, desires Casilda, who takes care of his injury, and then does everything to 'possess her' which ultimately leads to his death at the hands of Peribáñez. Weddings are generally the way in which honor is restored in the Spanish comedia, often as part of the (re)establishing of order by the ruler(s). In La vida es sueño, Segismundo restores Rosaura's honor by marrying her to Astolfo and marrying Estrella himself; in Tirso de Molina's El burlador de Sevilla o convidado de piedra (publ. 1630), the king marries all of Don Juan's 'aggrieved' ladies off to suitable partners. 
monarchs for their righteousness and loyalty. In El retablo de las maravillas, royal power is represented by the quartermaster and the soldiers, who, rather than serving as symbols of power, are attacked and the truth of their reality questioned. Thus, the villagers, for their part, are not protected, but on the contrary, albeit out of self-defense, experience brutal violence.

Luis Quiñones de Benavente (1581-1651) wrote a version of El retablo de las maravillas that was first published in $1645 .^{844}$ This entremés, however, not only adheres more closely to standard forms, such as ending with a song, it also defuses the content of the Cervantine version. Quiñones does away with the theme of limpieza de sangre, and instead only cuckolded husbands are unable to 'see' the retablo performance. This raises the comic aspect of the play, which then concludes harmoniously. ${ }^{845}$ In Los tejedores

844 Luis Quiñones de Benavente, Entremes famoso, el retablo de las marauillas, in: Luis Quiñones de Benavente, Ioco seria. Burlas veras, o reprehension moral, y festiua de los desordenes públicos: En doze entremeses representados y veinte y quatro cantados, Madrid 1645, fols. 178r-185r. (It was performed by a prominent actor and autor de comedias: "Representole Christoual de Auendaño.” [fol. 178r]).

845 In Benavente's burlesque farce, composed in verse, the number of characters is, in contrast to Cervantes' Retablo, greatly reduced (from eleven to six: Pilonga, Alcalde, El Sacristán Chichota, Regidor, Teresa, Escribano). The appearance of the scam artist/puppeteer Pilonga in the middle of the play, wearing a mask with a long nose who tickles the Alcade from behind and generally acts clownishly, makes it clear that the character is farcical (stage direction: "Sale Pilonga con vna mascara, con vnas narizes largas, y por detras del Alcalde le haze cosquillas con ellas en los carrillos, y el se dà de bofetadas, pensando que son moscas" [fol. 181v]). When the Alcade finally turns around, he falls to the ground in shock, and the other villagers are also frightened by the mask ("[stage direction: 'Buelue, y ve a Pilonga, y cae entierra, y los demas se espantan.'] ALC[ALDE]: Iesus, que mala vision. / REG[IDOR]: Tirte a fuera. / ESC[RIBANO]: Va de retro. / etc." [fol. 181v]). Pilonga then takes off the mask and announces that she is carrying a 'retable of wonders,' to be performed as a substitute for the plays on Corpus Christi that the place could not afford ("PIL[ONGA]: Que vengo a esta aldea / [...] / Con vn retablo que llaman, / de las marauillas ciento, / y pues el dia del Corpus, / por faltalles el dinero, / no tienen vustedes fiestas, / aqueste retablo haremos" [fol. 182r]). The Alcalde is prepared to pay her appropriately if she gives them a taste of the play right away. The reception of what is to be shown is, however, subject to a condition ("vn conque"), as Pilonga immediately explains, namely that the retable show can only be seen by the one whose wife is faithful. Unlike in the Cervantes' play, neither limpieza de sangre nor 'illegitimate birth' are mentioned; and although the play centers around the theme of honor this is treated lightly and only serves as background for comedy: "PIL.: Ay vn conque / ALC.: Venga el conque, / es de comer? / PIL.: Majadero, / es el conque que ninguno, / que tuuiere en el cabello, / alguna desigualdad, / en que tropieze el sombrero, / verà nada del retablo. / REG.: No lo atino. / Esc.: No lo entiendo. / [.. .] / PIL.: Digo pues, que el que tuuiere / la muger de ojos trauiessos, / de visitas, y recaudos, no podra ver mas que vn ciego, / cosa de lo que enseñare" (fols. 182r-182v). All those present immediately declare that they will be able to see "the 
[The Weavers], ${ }^{846}$ an entremés probably written in 1660 by Ambrosio de Cuenca (biographical data unknown), the burla does not unfold by means of a puppet play, but refers back, as the title already indicates, to the legend of

performance' without any problems. The first image that Pilonga evokes is a wild bull and the viewers run around confused or throw themselves to the ground, as if it were a 'real danger' ("PIL.: Pues ojo a letra, señores, / que el retablo va saliendo. / Todos se aparren, que sale / vn torazo Xarameño, / mas valiente, que el que tiene / a san Lucas el tintero. [stage direction: 'Corren todos, como que ay toro en el tablado, y el Alcalde se eche.'] Esc.: Iesus, y que bravo toro. / TER[ESA]: Echate hombre. / ALC.: Ya me echo" [fol. 183r]). In the second (and last) retablo scene evoked by Pilonga (in Cervantes, there are six), she 'lets' the flood waters of the Nile pour over the spectators and instructs them to get rid of their coats and cloaks and swim, which they then immediately put into action ("PIL.: Ya el toro se ha entrado dentro, / y aora se suelta el Nilo. / ALc.: Que niño es que se ha suelto? / PIL.: Que harà quien nadar no sabe, / fuera capas Caualleros. / ALc.: Iesus, y que golpe de agua. [stage direction: 'Quitanse las capas, y caperuzas, y hacen como nadan echados'] [fol. 183v]). Unlike in Cervantes, here the discrepancy between the spectators' 'participation in the action' and the 'not being able to see anything' is clearly shown to the external audience: all the spectators say in asides that they cannot see anything and therefore assume that they are cuckolded husbands and contemplate the punishment of their wives (e.g. "SAC[RISTÁN]: Moxaisos Alcalde? / ALC.: Bueno, / el agua hasta la cintura, / [A parte.] viue Christo que estò seco / mas que arenal por Agosto. / Esc.: A mi a la boca, y ya bebo. / REG.: [A parte.] Que sea yo el mas desdichado [fol. 184r] / de todos mis compañeros? / SAC.: [A parte] que quando todos se mojan, / ni aun húmedo no me siento, / oy perece mi muger. / REG.: [A parte] Oy a mi muger entierro. / ALC.: [A parte] Muger mia destas sos? / oy aurà degollamiento" [fols. 183v-184r]). With the words that the water floods would now retreat again, Pilonga disappears with all their coats. The villagers eventually notice the fraud, i.e. the theft, and decide to go after Pilonga ("PIL.: Ya se recogen las aguas. [stage direction: 'Vase, y lleuase las capas.'] / SAC.: Vamos a enjugarnos presto. / ALC.: Adonde està lo mojado? / que yo los veo muy secos. / REG.: Echos estamos vna agua. / ALC.: De congoja, yo lo creo. / SAC.: Cubramonos nuestras capas, / no nos haga mal el fresco. / ALC.: Valgate el Diabro la moça, / que nos trae al retortero. / REG.: Y la muger? / ALC.: Afufon. / SAC.: Y las capas? / ALC.: Volauerunt. / TER.: Alcalde, la del retablo / es ladrona, y por el viento / va bolando con las capas. / [...] / Tod[os]: Vamos tras ella al momento" [fols. 184r-184v]). Pilonga re-appears singing, gives back the stolen coats and explains that their wives have not cheated on them. The play concludes with a song sung by Pilonga and the Alcalde. ("PIL.: Las capas, que las lleuè / sahumadas se las bueluo. / ALc.: Como las capas mos traiga, / yo perdono el sahumerio. / PIL.: Sus mugeres son honradas, / a pagar de mi dinero. / AlC.: Y lo que vuested se lleua, / es a pagar de los nuestros. / PIL.: Como siendo tan Poeta, / no me dize algunos versos? / ALc.: Escuche aquesta cancion / que compuse a sus ojuelos. / Essos ojos criminales, / si me miran con enfado, / son trompetas, y atabales, / que dizen a los mortales, / suban, suban al terrado. [Repitan, y vanse.]" [fols. 184v-185r]).

846 Ambrosio de Cuenca y Argüello, Entremes delos Texedores, Manuscript Biblioteca Nacional de España (signature MSS/15813), n.d., fols. 46r-53v; edited by Henri Recoules, “Entremés de los Tejedores de Don Ambrosio de Cuenca," Anales Cervantinos 15 (1976), pp. 283-293, here pp. 285-293. The piece appears to have been written no earlier than 1660 in 
The Emperor's New Clothes that appears in the Conde Lucanor. In this play, the restriction of perception claimed by the swindlers consists solely in that only those of limpieza de sangre can see the cloth. However, this is embedded in the purely comic framework typical of the genre. Like Quiñones' Retablo, this play is also uncritical and lacks the clever and complex play between reality and fiction so evident in Cervantes. Here too the play is resolved harmoniously. The prank and the prankster are revealed, and the playful and merely entertaining character of the interlude itself is emphasized, particularly by the closing scene of singing and dancing by both deceivers and deceived. ${ }^{847}$ Despite the focus of this chapter specifically on $E l$

light of references to current events in the text. For example, the Alcalde wants to have a decent feast in honor of the marriage of the Infanta Mary Theresa, the youngest daughter of Philip IV, with Louis XIV, which led to peace between Habsburg Spain and France ("ALCALDE: La Infanta se ha casado de Castilla / y las paces con Francia se publican, / las campanas repican / y España en fiestas se recrea toda. / La villa ha de fundirse en fiesta y boda” [vv. 26-30, p. 286]). This is also proof that the text could not have served as a source for Cervantes (as, e.g., stated in Armando Cotarelo y Valledor, El teatro de Cervantes: Estudio crítico, Madrid 1915, pp. 571-591 ["El retablo de las maravillas"], here pp. 573 f., and following this Reed, The Novelist as Playwright [cf. note 779], p. 151).

847 In Los tejedores, the Sacristán has a love affair with Casilda, the mayor's wife, and asks his friend Carrizo to support him in a joke he intends to play on the Alcalde in revenge for his jealousy; he had promised to avenge Casilda, after she had been beaten by her husband in a violent quarrel and had come to him crying. The accomplice agrees. The next scene shows the Alcalde and the Regidor. The mayor decides that they will organize a splendid feast in the village in celebration of the wedding of the Infanta and the peace with France, (megalomaniacally he expresses: "Si Madrid hace fiestas, yo las quiero. / ¿Semos menos nosotros, majadero, / no soy josticia yo como el rey mimso?” [vv. $21 \mathrm{ff} .$, p. 285]). The problem is that they do not have adequate clothing or fabric in the village. The Escribano is assigned to collect all the clothes in the village. On his return, he brings along two 'strangers' who could produce the most beautiful fabrics in no time at all and for little money ("ESCRIBANO: Aquí traigo unos hombres extranjeros / que por pocos dineros / en breve tiempo harán tela mas buena / que Milán, que Venecia, y que Lucena” [vv. 55-58, p. 287]). That this is the disguised Sacristán and his accomplice Carrizo (stage direction: "Entran el sacristán, y Carrizo, vestidos de extranjeros, ridículamente" [p. 287]), the spectators already know from an aparte by Casilda ("El sacristán con un disfraz gracioso / castigará a este tonto malicioso [el alcalde]” [vv. 51 f., p. 286]). The disguised Sacristán then claims that they had traveled from Caramania - that is, from Turkish lands - via Rome to Spain, and the two were duly praised; now, he announces, he wants to produce wonderful fabrics ("unas telas prodigiosas") in a very short time, as they have not even been seen in Madrid; they are not expensive, because it is not about craftsmanship, but about science. ("SACRISTÁN: Nosotros, señor, venimos desde Caramania a Roma, / de allí pasamos a España / donde hemos hecho mil obras, / con el aplauso debido / a nuestras nobles personas. / [...] / [. . ] Quiero ahora / hacer en muy poco tiempo / unas telas prodigiosas / que no se han visto en Madrid / en la vida. [...] / [. . ] / [.. ] éste no es arte, / ésta es ciencia, que 
retablo de las maravillas, it should be noted that the other interludes in Cervantes' collection also use the 'play within the play' (or similar dramatic devices) to explore issues of reality versus fiction, although not with the

sin costa / haremos lo que quisiéreis. / [...] / [ . . E En media hora / estará tejida, y hecho / della el vestido o la ropa" [vv. 65-82, pp. 287]); only one condition is attached to it: the most magnificent, cheapest and fastest-producing substance can only be seen by cristianos viejos ("SACRISTÁN: Mas con una condición / que la tela más vistosa, / la más barata y más breve, / no la verá la persona / que algo tenga de judío / o morisco, aunque la pongan / en su presencia” [vv. 85-91, p. 288]). Enthusiastically, the Alcalde commissions the Sacristán, not caring if it is witchcraft or hellish work. ("REGIDOR: [...] No, amigos / son de los infiernos sombras / esas telas. Escribano: Y aun son brujos / los que tal prometen. / [. . . / ALCALDE: [... j iQué importa / que sea de los infiernos! / Yo las quiero. Quien blasona / de christiano viejo excusa / ver aquí su ejecutoria" [vv. 93-100, p. 288]). The two cheaters 'set to work'; the fact that they merely pretend to weave and that their company is a merry prank that is to be played out of revenge on the Alcalde is disclosed to the readers/spectators from the beginning ("SACRISTÁN: Ven, Carrizo, que hoy verás / la venganza más graciosa / que el mundo celebra. / [...] / Al alcalde no sólo doy papilla / pero pienso engañar a toda la villa. / [. . ] / Así vengo a Casilda soberana. / [. . . Arrímate al telar, haz que tejemos" [vv. 105-122, pp. 288 f.]; stage direction: "Salen el sacristán y Carrizo como que tienen un telar y que tienen" [p. 290]). When the Alcalde enters and is frightened, he had thought he was an Old Christian, he realizes that he is unaware of the weaving pattern the two refer to, he, too, pretends to see something ("ALCALDE: ¡Lleve el diablo mi alma si veo cosa! [aparte] / [. . ] / ¿Hay mayor desventura? / ¡Y pretendía ayer familiatura! / Disimular es fuerza. [aparte]" [vv. 130-137, p. 289]). The same thing then happens to the Regidor, who also - obviously confused - decides to adhere to the maxim of 'unconditional dissimulation' (“REGIDOR: [. . . ] O soy judío, / o estoy ciego. ¡Por Dios, esto ignoraba! / ¡Y un hijo colegial pensaba! [aparte] / [...] Que el vestido ha de ver la villa toda / y yo no; que el alcalde lo haya visto / mal mi pesar resisto, / disimular me es fuerza, aunque lo sienta, / que no es bien que publique yo mi afrenta. [aparte]" [vv. 156-168, p. 290]). Neither one admits that in truth they have not seen anything, and both are afraid to confirm that they are not Old Christians and affirm for themselves the need to hide this. Finally, the Alcade puts on the finished 'clothes' ("SACRISTÁN: Aquí está ya el vestido, ropa fuera. / [...] / Veamos la ropilla, si está buena. [stage direction: 'Van lo vistiendo']” [vv. 185 ff., p. 291]). All comment on the invisible robe on the mayor now dressed only in his shirt (“ALCALDE: [aparte:] ¿Hay más notable pena? / ¿Hay desdicha que venga con más prisa? / ¡Que esté vestido yo estando en camisa!” [vv. $208 \mathrm{ff} .$, p. 291]), at the same time the apartes make clear again that they feign everything in order not to be decoded as cristianos nuevos (now also the EsCRIBANO: "[aparte:] [...] Todos ven lo que yo ignor[o.] / Sin duda soy judío, hereje, o moro. / [. . ] / [.. ] jFamoso talle! / [aparte:] Fuerza es disimular. [...]” [vv. 193-198, p. 291]). But when the three councilors are then among themselves, they finally, after they have mutually assured each other of their 'impeccable origin,' finally tell each other that none of them can see the dress and that the Alcalde is really just wearing his underwear and the fraud is revealed. ("Alc.: Escribano, ¿vos véis algún vestido? / EsCR.: Decidme, ¿soy hidalgo? AlC.: No lo dudo. / Pues, alcalde, advertí que estáis desnudo. / REG.: ¿Cristiano viejo soy? ALC.: Yo só testigo. / ¿Qué decís, regidor? / [...] / REg.: Sólo en camisa os veo. AlC.: Estas traiciones / sin castigos no queden pues 
same complexity or satirical-critical vigor (e.g., El vizcaíno fingido, El viejo celoso and especially La cueva de Salamanca). This aspect is also evident in the Cervantine comedias (cf., e.g., La entretenida and, in particular, Pedro de Urdemalas). It is also crucial to draw attention once again to the obvious parallel here to Cervantes' most important narrative text, Don Quijote, whose major theme is the skeptical thesis of the unreliability of sensory perception. In both El retablo de las maravillas and the novel, the Aristotelian model is shown to be problematic, but in neither case does the author offer an alternative means for understanding and getting along in the world, a lack to which the endings, the violence of the interlude, and the premature death of the protagonist of the novel, seem to point.

In conclusion, in distilling the above analysis, we can point to a concise denominator: reference to contemporary discussions of skepticism. While this element appears in all the plays discussed in this work, Cervantes is the only one

podemos" [vv. 220-228, p. 292]). The next scene shows the Sacristán, Carrizo and Casilda, who are happy about their successful burla ("SACR.: Ellos quedan bien burlados. / CASILDA: Pague su malicia necia / el tontón de mi marido" [vv. 229 f., p. 292]). As the deceived approach and Casilda advises the Sacristán to hide better, he replies in a metatheatrical commentary that refers to the simple structure, playful, jocular character, and entertaining function of the genre entremés: “[...] Yo no quiero / Que esconderse es de comedia, / y éste no es más que entremés / donde los cuentos se juegan” (vv. 237-240, p. 292). The Sacristán reveals himself to the Alcalde and tells him that he has pulled this joke on him because of his jealousy and because he treated his wife Casilda so badly ("SACR.: [. . .] Yo soy, / alcalde, y por tus quimeras / y porque a Casilda tratas / tan mal, de aquesta manera / te he burlado" [vv. 243-247, p. 293]). There is no contradiction on the part of the doubly deceived Alcalde - after all, as the spectators know, there is cause for jealousy - no argument takes place, but everything dissolves into peaceful pleasure and mutual joking. When the Regidor agrees with the Sacristán and proposes to celebrate the burla together with dance and music, the Alcalde agrees. They sing and dance (stage direction: "Cantan y bailan" [p. 293]), a chorus of women comments on events and conflict with the words: "MUJERES: Si el alcalde es celoso / sufra la burla, / y si burlas no quiere / cállese y sufra" (vv. 253-256, p. 293), to which the Alcalde replies: "Bien se ve que no sufro / cosa ninguna, / que a quien sufre le visten / y a mí desnudan” (vv. 257-260) and concluding this piece - turns to his wife Casilda after she expresses doubts about his sincerity: "Como guarde mi honra / nada se arriesga, / que aunque quede en camisa / no habré vergüenza" (vv. 265-268, p. 293). The framework for the fusion of the narrative of The Emperor's New Clothes with the limpieza de sangre aspect of Cervantes' entremés that is found in Los tejedores is common for the comic genre per se: in the combination of adultery and burla, the wife (Casilda) and lover (the Sacristán - besides the characters of 'dumb' village dignitaries also the 'lecherous' and 'witty' church servants are standard characters of the 17th century entremés) triumph over the betrayed husband (the Alcalde). In addition to the racist limpieza de sangre discourse, the piece also makes use of contemporary xenophobic stereotyping of the Turks, solely for the sake of comic effect. 
to write a comic parody. The content of his play makes clear how dominant ideologies can influence what the senses perceive. In this way, the skeptical repertoire of arguments against Aristotelian epistemology is to some extent supplemented by a new perspective. The imperative felt by the audience of the 'play within the play' to be perceived and to perceive themselves as legitimately-born Old Christians compels them to 'subjectively' see something that 'objectively' does not exist. The Cervantine text (in a similar way to the other dramas addressed) goes beyond the 'staging' of the basic thesis of skepticism. The a-typical violence of Cervantes' ending, which lends it a particularly high semiotic value, makes it clear that there are situations in which doubt about perception and 'status of being' can only go so far. In the end, the stab of a sword is irrefutable and has real and dire consequences. One can understand the insistence, as arises from Cervantes' play, that one must ultimately distinguish between what is real and what is not as a particularly emphatic commentary on this question. The sudden shift from harmless ridicule of a crowd of ignorant villagers into bloody chaos points to the fact that serene indifference to the question of the reality, while perhaps intellectually appealing, is, pragmatically speaking, a potentially ruinous position. 